\title{
Otizm Spektrum Bozukluğu Olan Çocukların Sosyal İletişim Becerileri ve Dil Gelişim Özellikleri*
}

\author{
Meral Çilem Ökcün-Akçamuş ${ }^{* *}$ \\ Ankara Üniversitesi
}

Öz

Dil ve iletişim alanında yaşanan güçlükler, otizm spektrum bozukluğunun (OSB) tanı ölçütlerinden birisidir ve bu güçlükler OSB olan çocuklarda otizmin şiddetini belirleyen önemli bir değişken olarak ele alınmaktadır. OSB olan çocukların dil gelişiminde heterojen bir yapı olduğu kabul edilmektedir. OSB olan bazı çocuklar sözel dili hiç edinemezken, bazı çocuklarda normal gelişim gösteren akranlarına yakın bir sözel dil kullanım örüntüsü görülebilmektedir. Bu derleme çalışmasında OSB olan çocukların dil ve iletişim becerilerine ilişkin gelişimsel özellikleri incelenmiştir. OSB olan çocuklarda söz öncesi dönemde sözel olmayan sosyal iletişim becerilerine, sözel dil döneminde dilin bileşenlerine ilişkin sendroma özgü gelişimsel özellikler/bozukluklar görülmektedir. $\mathrm{Bu}$ nedenle bu derleme çalışmasında OSB olan çocukların söz öncesi dönemde sözel olmayan sosyal iletişim becerilerine yönelik gelişimleri ele alınacaktır. Bunun yanı sıra sözel dil döneminde olan OSB olan çocukların dilin biçimbirim bilgisi/sözdizimi, anlam bilgisi ve kullanım bilgisi bileşenlerine yönelik gelişimsel özellikleri incelenecektir. Alanyazından derlenen bu çalışmanın OSB olan çocuklarda dil gelişimi üzerine çalışan öğretmenlere ve araştırmacılara yol göstereceği düşünülmektedir.

Anahtar sözcükler: Otizm spektrum bozukluğu, dil gelişimi, söz öncesi sosyal iletişim becerileri, biçimbirim bilgisi/ sözdizimi, kullanım bilgisi, anlam bilgisi, oyun

\footnotetext{
*Bu çalışma, Meral Çilem ÖKCÜN-AKÇAMUŞ'un Ankara Üniversitesi Eğitim Bilimleri Enstitüsü'nde Prof. Dr. Funda ACARLAR'ın danışmanlığında hazırladığı doktora tezinden türetilmiştir.

${ }^{* *}$ Sorumlu Yazar: Öğr. Gör. Dr., Ankara Üniversitesi, Eğitim Bilimleri Fakültesi, E-Posta:meralcilem@gmail.com
} 


\title{
Social Communication Skills and Language Development of Children with Autism Spectrum Disorders
}

\begin{abstract}
Difficulties in language and communication are diagnostic criteria of autism spectrum disorders (ASD) and these difficulties are taken as an important variable in determining the severity of the disorder for the children with ASD. It is accepted that language development of children with ASD is heterogeneous. While some of the children can never acquire language, some of them may show language use similar to their peers with typical development. In this review developmental characteristics of children with ASD in language and communication skills are examined. Children with ASD show developmental characteristics/impairments specific to the disorder in pre-linguistic social communication skills and in language components. Therefore, in this review development of children with ASD in pre-linguistic nonverbal social communication skills is discussed. In addition to this, developmental characteristics of verbal children with ASD in morpho-syntax, semantics, and pragmatics which are language components are also examined. This review provides a guide to teachers and researchers who work on language development of children with ASD.
\end{abstract}

Keywords: Autism spectrum disorder, language development, prelinguistic social communication skills, morpho-syntax, pragmatics, semantics, play

Otizm spektrum bozukluğu (OSB), sosyal etkileşim ile sosyal iletişimde kalıcı bozukluklar ve sınırlı tekrarlayıcı davranışlarla karakterize olan ve gelişimin erken dönemlerinde ortaya çıkan nörolojik gelişimsel bir bozukluktur (American Psychiatric Asociation [APA], 2013). Amerikan Psikiyatri Birliği'nin yayımladığ Ruhsal Bozuklukların Tanısal ve Sayımsal El Kitabı'nın (Diagnostic and Statistic Manual of Mental Disorders-5 [DSM-5]) sınıflamasına göre, OSB olan çocukların sosyal etkileşim ve dil gelişimi alanında yaşadıkları güçlükler sendorumun tanı ölçütlerinden biridir ve OSB'nin şiddeti, çocukların sosyal iletişim bozukluklarının ve sınırlı tekrarlayıcı davranışların şiddetine göre belirlenmektedir (APA, 2013). DSM-5'de OSB olan çocukların sosyal etkileşim ve dil gelişimi alanında yaşadıkları güçlükler; sosyal duygusal karşılıklılıkta (socialemotional reciprocity) güçlükler, sözel olmayan sosyal iletişim davranışlarında sınırlılıklar ve sosyal ilişki geliştirmede, bu ilişkileri sürdürme ve anlamada güçlükler olarak sıralanmıştır. Sosyal duygusal karşılıklılıkta yaşanan güçlüklere örnek olarak; karşılıklı sohbeti sürdürmede, ilgilerini, duygularını ve isteklerini paylaşmada sınırlılıklar ve sosyal ilişkileri geliştirmede, bu ilişkileri anlama ve sürdürmede güçlükler gibi davranışlar gösterilmiştir. Sözel olmayan iletişim davranışlarındaki güçlükler için ise göz kontağı ve beden dilini kullanmada sınırlılıklar, jestleri kullanma ve anlamada güçlükler ile sözel olmayan iletişim davranışları ve yüz ifadelerinin tümünde sinırlılıklar örnek davranışlar olarak gösterilmiştir. Farklı sosyal bağlamlara göre davranışları düzenleme, akranlarla sembolik oyun oynama ve akranlara karşı ilgisizlik ise ilişkileri anlama ve ilişki geliştirip sürdürmede yaşanan sınırlılıklara örnek gösterilmiştir. DSM-5 ölçütlerinde görüldüğü üzere, OSB'li çocukların sosyal iletişim davranışlarında yaşanan güçlükler tanılama sürecinde önemli bir yer tutmaktadır. OSB olan çocuklarda sosyal iletişim becerilerinde yaşanan güçlüklerin iki neden ile önemli olduğu 
söylenebilir. Bunlardan birincisi, iletişim problemlerinin OSB'nin temel semptomu olmasıdır. İkincisi neden ise iletişim problemlerinin OSB olan çocukların sosyal ve bilişsel problemleri ile iç içe olmasıdır (Schopler ve Mesibov, 1985).

OSB olan çocuklarda, sosyal iletişim becerilerinin kazanımında gelişimle birlikte değişen zayıf ve güçlü oldukları yanlar vardır (Mundy ve Sigman, 1989). OSB olan çocuklarda dil ve iletişim bozuklukları, konuşmada gecikme ya da konuşmanın hiç ortaya çıkmamasından, sözcük ve cümleler kuran çocukların dili sosyal etkileşimsel bir amaca yönelik etkili kullanmada yani dilin işlevsel kullanımında sorunlar yaşamalarına kadar geniş bir dağılımda görülebilir (Paul, 2007; Wilkinson, 1998). OSB olan çocuklarda, söz öncesi dönemde jestler (Töret ve Acarlar, 2011), taklit (Charman ve diğ., 1997), ortak dikkat (Mundy ve Markus, 1997) gibi sözel olmayan sosyal iletişim davranışlarda sınırlılıklar yaşanırken, sözel dilin kazanıldığ 1 durumlarda ise çocukların dil gelişim özelliklerinde farklılıklar görülmektedir. Çocuklarda ses bilgisi, sözdizimi ve anlam bilgisi kısmen iyi gelişirken, kullanım bilgisi bileşeninde anlamlı ve istikrarlı bozukluklar görülmektedir (Tager-Flusberg, Paul ve Lord, 2005). Bu çalışmada OSB olan çocukların dil ve iletişim becerilerinde görülen gelişimsel özelliklerin alanyazında yapılan araştırmalar doğrultusunda kapsamlı olarak ele alınması hedeflenmiştir. OSB olan çocuklarda dil ve iletişim becerilerinde görülen bozuklukların kapsamlı olarak incelenmesinin, çocukların dil ve iletişim becerilerinin heterojen yapısının daha iyi anlaşılmasına yardımcı olacağı ve alanda çalışan eğitimciler ve araştırmacılar için yol gösterici olacağı düşünülmektedir.

Normal gelişim gösteren çocuklarda sözel dilin ortaya çıkmasından önce jestler, taklit, ortak dikkat başlatma gibi bazı sosyal iletişim amaçlı davranışlar ortaya çıkar (Carpenter, Nagell ve Tomasello, 1998). Bu sözel olmayan sosyal iletişim davranışlarının, dil gelişiminin öncülü ve dil gelişiminin önemli bir yordayıcısı olduğu düşünülmektedir (Bruner, 1975; Carpenter ve diğ., 1998). Bu nedenle bu çalışmada OSB olan çocukların dil ve iletişim gelişimi özellikleri, söz öncesi iletişim becerilerini de içeren sözel olmayan sosyal iletişim becerilerini ve sözel dil gelişimini içerecek biçimde iki aşamalı olarak ele alınmaktadır.

\section{OSB Olan Çocuklarda Sözel Olmayan Sosyal İletişim Becerilerinin Gelişimi}

İnsanlar doğumdan itibaren sosyal varlıklardır (Carpenter ve diğ., 1998). Yenidoğan bebekler, doğumdan hemen sonraki saatlerde yetişkinlerin oral motor bazı hareketlerini taklit etmek gibi sosyal davranışları gösterebilirken (Meltzoff ve Moore, 1977; 1983), Trevarthen'e göre (1979) bu sosyal davranışlar ortalama 1-2. aylarda yetişkinle yüz yüze etkileşimlerin başlaması ile hızlı bir biçimde artar (akt., Carpenter ve diğ., 1998). Bebeklerin bu davranışları, bağlamsal uyaranlara tepki olarak ortaya çıkmakta ve iletişimsel bir amaç içermemektedir (Owens, 2012). Normal gelişim gösteren bebeklerde, ortalama 8. ayda zihinde temsil etmenin gelişmesi ile birlikte iletişim amaçlı davranışlar görülmeye başlar. Bu dönemde bebekler, ebeveynlerin dikkatini çekmek ve istedikleri bir şeyi elde etmek için iletişimsel eylemleri kullanmaya başlarlar. Bu iletişimsel eylemler, 8 ve 10. aylar arasında başlayan amaçlı iletişim döneminin ilk belirtileridir ve bu dönemde iletişim, nesneyi annenin göreceği şekilde tutma, gösterme gibi jestlerle kurulmaktadır (Paul, 2008). Amaçlı iletişimin gelişimi ile birlikte gelişmeye başlayan sözel olmayan sosyal iletişim becerileri, bebeklerin çevrelerindeki bireylerle sözel dil olmadan iletişime girmelerini sağlar (Carpenter ve diğ., 1998) ve sözel dil gelişiminin temellerini oluşturur (Bruner, 1975).

OSB olan çocukların sözel olmayan sosyal iletişim becerilerinde güçlükler görülmektedir. OSB tanıs1 almış çocukların tanı almadan önceki video kayıtlarının incelenmesine ve aile raporlarına dayanan geriye dönük çalışmalar sonucunda, normal gelişim gösteren akranları ile karşılaştırıldığında OSB olan çocukların yaşamlarının ilk, ikinci ve üçüncü yıllarında insanlara bakma sıklıklarında düşüklük, düşük oranda göz kontağı kurma, ismi ile çağırıldığında tepki vermeme, etkileşimsel oyunlara katılımda sınırlılıklar, motor taklit becerilerinde sinırlılıklar, akranlarına oranla daha basit düzeyde oyun oynama, sembolik oyun oynama becerilerinin olmaması gibi sosyal gelişim özellikleri gösterdikleri bulunmuştur. OSB olan çocukların yaşadıkları diğer sosyal iletişim bozuklukları ise, gösterme ve işaret etme yolu ile ilgiyi paylaşmadaki sınırlılıklar, iletişimsel jestleri yanıtlamada bozukluklar, konuşma sesi dışı sesletimler ve diğer bireyleri araç gibi 
kullanma davranışları olarak sıralanabilir (Chawarska ve Volkmar, 2005). Sosyal uyum sağlama, ortak dikkat becerileri, duygusal ipuçlarına tepki verme becerileri (Dawson ve diğ, 2004; Dawson, Meltzoff, Osterling, Rinaldi ve Brown, 1998), taklit becerileri (Stone, Ousley ve Littleford, 1997) ve sembolik oyun (Brown ve Whiten, 2000; Charman ve Baron-Cohen, 1997) OSB olan çocukların hem normal gelişim gösteren hem de gelişim geriliği olan çocuklardan daha fazla güçlük yaşadıkları alanlardır. İlerleyen bölümde OSB olan çocukların sözel olmayan sosyal iletişim davranışlarından jestler, taklit ortak dikkat ve oyun becerileri ele alınacaktır.

\section{OSB Olan Çocuklarda Jest Kullanımının Gelişimi}

Jestler, genel olarak elleri, parmakları, kolları, yüz ifadelerini ve vücut pozisyonlarını kullanarak iletişim amacıyla üretilen eylemler olarak tanımlanmaktadır. Çocuklarda gösterici (deictic) jestler ve temsili (representional) jestler olmak üzere iki tür jest davranışı görülmektedir (Iverson ve Thal, 1998). Gösterici jestler, bağlamda olan dışsal bir uyaranın işaret edilmesi veya gösterilmesi amacıyla yapılan davranışlardır (Gullberg, Bot ve Volterra, 2010). Gelişimin erken dönemlerinde gösterici jestler göstermek, işaret etmek, uzanmak ve vermek gibi davranışları içerir (Iverson ve Thal, 1998). Bates, Camaioni ve Volterra (1975), gösterici jestlerin davranışın biçimine göre yakınsal (contact) ve uzaklık (distal) jestleri olmak üzere ikiye ayrıldığını belirtmişlerdir. Yakınsal jestler, nesne ya da etkileşimde bulunulan birey ile dokunsal teması gerektirirken (örn., oyuncak verme, yetişkinin elini itme), uzaklık jestleri, işaret etme gibi nesneye ya da bireye dokunmadan nesne ya da etkinliği refere etmeyi içeren jestlerden oluşur (Crais, 2007). İletişim amaçlarına göre ele alındığında gösterici jestler, istek (poto-imperative) ve yorumlama (proto-declarative) jestleri olarak ikiye ayrilırlar (Bates ve diğ., 1975). İstek jestleri çocukların istedikleri nesne veya etkinliği elde etmek için, yorumlama jestleri ise nesneye iliş̧kin dikkatin paylaşımı ve yetişkinin dikkatini herhangi bir dışsal uyarana çekmek için kullanılan jestlerdir (Iverson ve Thal, 1998). Temsili jestler, belirli bir bağlamı sembolik olarak temsil eden jestlerdir (Crais, 2007) ve kullanımlarına göre nesne ile ilişkili jestler (bardaktan içiyormuş gibi yapma vb.) ve uzlaşıma dayalı jestler (el sallama vb.) olarak ikiye ayrılabilir. Jestler biçimlerine göre veya iletişim işlevlerine göre kategorilere ayrılsalar da tüm jestler iletişim amacı ile üretilen davranışlardır (Iverson ve Thal, 1998). Normal gelişim gösteren çocuklarda gösterici jestler amaçlı iletişimin başlaması ile ortalama 8. ayda gelişmeye başlar. Temsili jestler ise birden fazla gösterici jestin kazanılmasının ardından ortaya çıkmaya başlar (Crais, Douglas ve Campell, 2004) ve nesne ile ilişkili olan temsili jestler genellikle ilk sözcüklerin çıkması ile eş zamanlı olarak ortaya çıkar (Acredolo ve Goodwyn, 1988). Normal gelişim gösteren çocuklarda jestler amaçlı iletişimin en tutarlı erken işaretlerinden biridir ve erken sosyal iletişim gelişiminin gözlenebilmesi için bir pencere oluşturur (Crais ve diğ., 2004). Jestler hem erken dönemde çocukların iletişim motivasyonunu hem de iletişim yeterliliğini göstermesi açısından da önemlidir (Sigman ve Ruskin, 1999).

OSB olan çocuklar ile normal gelişen çocuklar arasında, iletişim amaçlı jestlerin kullanımında dikkat çekici derecede farklılıklar bulunmaktadır (Camaioni, Perrucchini, Muratori, Parrini ve Cesari, 2003). Alanyazında yapılan çalışmalarda OSB olan çocukların jestlerin kazanımında güçlükler yaşadıkları, jest kullanımlarının geliştiği durumlarda bile, kullanılan jest repertuarının çoğunlukla gösterici jestlerden oluştuğu, gösterici jest kullanımlarında ise istediği nesneye uzanma gibi istek (imperatives) jestlerinin kullanıldığı, ilgisini çeken bir nesneye bakma, sonra yetişkine gösterme gibi yorumlama (declaratives) jestlerinin kullanımında sinırl1liklar olduğu bulunmuştur (Camaioni ve diğ., 2003; Stone, Ousley, Yoder, Hogan ve Hepburn, 1997, Töret ve Acarlar, 2011).

OSB olan çocukların, normal gelişim gösteren çocukların yanı sıra diğer gelişim yetersizlikleri olan çocuklarla karşılaştırıldığında da jestlerin kullanımında güçlükler yaşadıkları görülmektedir. Stone, Ousley, Yoder ve diğerleri (1997), 27-38 aylık OSB olan çocukları, kronolojik yaş, zeka yaşı ve ifade edici sözcük dağarcığına göre eşleştirilmiş gelişimsel geriliği ya da dil bozukluğu olan çocuklardan oluşan kontrol grubuna göre daha az sıklıkta iletişimsel jest davranışları gösterdiklerini, iletişim davranışlarının ise daha çok nesne ya da etkinlik isteme davranışlarından oluştuğunu bulmuşlardır. Araştırmada OSB olan çocukların, gelişim geriliği/dil bozukluğu olan kontrol grubuna göre daha fazla istek jesti kullandıkları ve daha az yorumlama jesti kullandıkları 
bulunmuştur. OSB olan çocukların kullandıkları sözel olmayan iletişim biçimleri incelendiğinde, OSB olan çocukların nesneye işaret etme, nesneyi gösterme ya da iletişim amaçlı göz kontağı kurmak gibi karmaşık düzey amaçlı iletişim davranışlarından daha çok yetişkinin elini tutarak manipüle etmek yoluyla iletişim kurdukları görülmüştür. OSB olan çocuklar, gösterici jestlerin yanı sıra temsili jestlerde de sınırlılıklar göstermektedirler (Wetherby, 2006). Jest kullanımı gelişen otizmli çocuklar, çoğunlukla yetişkininin elini manipüle ederek nesneye götürmek gibi dokunma jestlerini tercih etmekte ve el sallama, başı ile onaylama ya da reddetme hareketi yapma gibi taklit ile öğrenilen sosyal rutin jestlerini kazanmada sorunlar yaşamaktadırlar (Sowden, Perkins ve Clegg, 2011).

İletişim amaçlı jest kullanımları açısından OSB olan, normal gelişen ve gelişim geriliği olan çocukları karşılaştıran bu araştırmalar genel olarak incelendiğinde jest kullanımlarındaki sınırlılıkların, OSB olan çocukları hem normal gelişim gösteren hem de gelişim geriliği olan çocuklardan ayırt edici bir özellik olduğu söylenebilir. OSB olan çocukların jestlerde yaşadıkları sınırlılıklar çok erken yaşlarda ortaya çıkmaktadır (Wetherby, Watt, Morgan ve Shumway, 2007). Shumway ve Wetherby’ın (2009) çalışmasına göre, OSB olan çocuklarda tanı almadan önce, 18-24. aylar arasında, normal gelişen ve gelişim geriliği olan çocuklardan daha düşük sıklıkta iletişimsel jestlere yönelik davranışlar görülmektedir. Araştırmacılar, jest kullanımlarındaki eksikliklerin ilk iki yıl içinde ortaya çıktığını ve 18-24 ay arası ortaya çıkan düşük jest kullanım sıklığının aynı zamanda OSB'nin temel bozukluklarından biri olduğunu öne sürmektedir. Bu bulguyu destekleyen Zwaigenbaum ve diğerleri (2005) yaptıkları araştırmada, OSB tanısı alan çocukların 12. ayda OSB risk grubu olan çocuklardan daha düşük oranda göz kontağı kurmaları ve daha az oranda jest kullanmaları ile ayrıldığını bulmuşlardır. Jestlerde yaşanan güçlüklerin gelişimin erken dönemlerinden itibaren başladığını gösteren başka bir araştırma da Colgan, ve diğerleri (2006) tarafından gerçekleştirilmiştir. Colgan ve diğerleri, yaptıkları çalışmada, geriye dönük video kayıt analizi ile 9-12 aylar arası normal gelişen ve OSB tanısı olan çocukların iletişim amaçlı jest davranışlarını incelemişlerdir. Araştırmanın sonucunda OSB olan çocukların normal gelişen çocuklardan daha az çeşitlilikte jest davranışları gösterdikleri, kullanılan jest sayısı ve çocuğun başlattığı jestlerin oranının ise normal gelişen çocuklarla OSB olan çocukları ayırt etmediği bulunmuştur. OSB olan çocuklarda 18-24 aylar arasında ilgi odağını paylaşmak amacı ile (yorumlama amaçlı) gösterici jestlerin kullanımı, erken dönem göz kontağı kurma davranışları ve jestlerde yaşanan sınırlılıklar nedeniyle özellikle önem kazanmaktadır. Erken dönemde OSB olan çocukların, başkasının bakışını takip etme ve başkasının ilgi odağına odaklanma gibi bakma ile ilgili sorunlar yaşaması durumunda, ilgi odağını paylaşmak amaçlı gösterici jestlerin kullanımı da olumsuz yönde etkilenebilmektedir (Shumway ve Wetherby, 2009).

Sonuç olarak, araştırmalar, normal gelişim gösteren ve gelişim geriliği olan çocuklarla karşılaştırıldıklarında OSB olan çocukların, jest kullanımlarında anlamlı olarak düşük performans gösterdiklerini ve yorumlama amaçlı gösterici jestlerin kullanımında ve temsili jestlerde daha fazla sınırlılık yaşadıklarını göstermektedir. OSB olan çocukların jest kullanımında yaşadıkları sınırlılıklar gelişimin erken dönemlerden itibaren başlamakta ve özellikle jestlerin kazanımında gecikmelerle kendini göstermektedir. Jestlerin kazanıldığı durumlarda ise OSB olan çocukların jest repertuarı çoğunlukla isteme amaçlı ve dokunsal jestlerden oluşmakta, yorumlama amaçlı jestlerinde ve temsili jestlerde güçlükler yaşanmaktadır. OSB olan çocuklarda jestlerde yaşanan sınırlılıkların, jestlerin amaçlı iletişimin en erken göstergelerinden biri olması (Crais ve diğ., 2004) ve jest gelişiminin dil gelişimi ile ilişkili olması nedeni ile (Bates ve diğ., 1975; Iverson ve Goldin-Meadow, 2005), dil ve iletişim becerilerinde önemli bir yeri olduğu düşünülmektedir.

\section{OSB Olan Çocuklarda Taklit Gelişimi}

Taklit, gözlemlenen davranışların kopyalanması olarak tanımlanan bir erken dönem sosyal iletişim becerisidir (Zaghlawan, 2011; Zentall, 2006). Taklit becerileri, hem taklit edilen eylemin gerçekleştiği vücut bölümüne göre ve hem de taklit edilen eylemin gerçekleştiği zamana göre sınıflandırılmaktadır. Alanyazında eylemin gerçekleştiği vücut bölümüne göre nesneli taklit (object imitation), motor taklit (motor imitation) ve ses taklidi (vocal imitation) olmak üzere üç tür taklit becerisinden söz edilmektedir (Rogers, Hepburn, Stackhouse ve Wehner, 2003). Nesneli taklit, nesnelerle yapılan eylemlerin taklit edilmesini içerirken (Stone, Ousley ve 
Littleford, 1997), motor taklitler, nesne içermeyen vücut hareketlerinin, büyük-küçük kas motor eylemlerin ve jestlerin taklidini içeren taklit türüdür (Rogers ve diğ., 2003; Stone, Ousley ve Littleford., 1997; Zaghlawan, 2011). Rogers ve diğerleri (2003), motor taklitlerden oral motor taklitleri ayırmış ve ayrı bir taklit türü olarak ele almıştır. Oral motor taklitler, yüzde ağız bölgesi ile ilgili eylemlerin taklidini içermektedir (örn., dil çıkarıp ağzın iki yanına hareket ettirmek, öpücük hareketi yapmak). Ses taklitleri ise, anlamlı olan ve olmayan sözcükler ve seslerin taklitlerinden oluşmaktadır (Zaghlawan, 2011).Taklit edilen eylemin gerçekleştiği zamana göre, anında taklit becerileri (immediate imitation), gecikmiş taklit becerileri (delayed imitation) ve ertelenmiş taklit becerileri (deferred imitation) olmak üzere üç tür taklit becerisi bulunmaktadır. Anında taklit becerileri, gözlemlenen bireyin yaptığı eylemin aynısının, gözlemlenen birey ile eş zamanlı yapılması olarak tanımlanırken; gecikmiş taklit becerileri, gözlemlenen eylemin model alınan kişiden kısa bir süre sonra tekrarlanması olarak tanımlanmaktadır. Ertelenmiş taklit becerilerinde ise çocuğun önceden gözlemlediği eylemin aynısını, uzun bir süre sonra tekrar model olunmadan yapması söz konusudur (Nadel, 2014).

Bebeklerin taklit becerilerini kazanmalarının, hem sosyal hem de bilişsel bakış açısına göre önemli bir gelişimsel basamak olduğu kabul edilmektedir (Meltzoff, 1988). Uzgiris (1981), taklit ile sosyal etkileşimler arasında bir ilişki olduğunu vurgulamış, taklidin bebeklik döneminde karmaşı gözlemleri anlama ile karşıllıklı sosyal iletişim olmak üzere iki işleve hizmet ettiğini belirtmiştir. Dolayısıyla taklit, bebeklik döneminde öğrenme ve sosyal iletişim amacı ile kullanılmaktadır (Nadel, 2006). Taklit bebeklerin yeni davranışları öğrenmelerinde önemli bir araç olmasının yanı sıra, öğrenme için araç olma işlevini hayat boyu sürdürmektedir (Jones ve Herbert, 2006). Sosyal iletişim amaçlı yapılan taklitler, normal gelişen ve gelişim geriliği olan çocuklarda amaçlı iletişimin temel yapı taşlarından biridir (Nadel, Guerini, Peze ve Rivet, 1999).

Normal gelişim gösteren çocuklarda taklit, bebeklikte gelişimin erken dönemlerinde ortaya çıkmaktadır. Bebekler yüz-ağız bölgesi hareketlerini taklit etme şeklinde ilkel bir temsili yeterlilikle doğmaktadırlar (Meltzoff ve Moore, 1977; 1983). Hulit ve Howard'a göre (1993), bebekler 1-4. aylarda başkası tarafindan taklit edilen kendi davranışlarını tekrarlar, 4-8. aylar arası daha önce spontan olarak ürettikleri davranışları tekrarlarlar (akt., Kuder, 1997). Amaçlı iletişimin başlaması ile birlikte, diğer bireylerin amaçlı varlıklar olduklarını anlamaya başlarlar. 12. ayda bu bilgiyi taklit bağlamında bir eylemi yapan kişinin ne yapmaya çalıştığı konusunda karar vermekte ve gözlemlediği eylemin hangi öğesini taklit edeceğine karar vermekte kullanırlar (Carpenter, 2006). Ortalama 18. ayda ise ertelenmiş taklit becerilerini kazanılmaya başlar (Nadel, 2006).

OSB olan çocuklarda görülen sözel olmayan sosyal iletişimsel bozukluklarından biri de taklit gelişiminde yaşanmaktadır. Alanyazında OSB olan çocukların, taklit becerilerinde normal gelişen akranlarına göre sınırlılıklar yaşadıklarını (Charman ve diğ., 1997; Dawson, Meltzoff, Osterling ve Rinaldi, 1998; Rogers ve diğ., 2003; Stone, Lemanek, Fishel, Fernandez ve Altemeier, 1990; Turan ve Ökcün-Akçamuş, 2013), farklı gelişimsel geriliği olan çocuklara göre taklit performanslarının anlamlı derecede düşük olduğunu gösteren birçok çalışma bulunmaktadır (Charman ve diğ., 1997; Rogers ve diğ., 2003; Stone, Ousley ve Littleford, 1997; Turan ve Ökcün-Akçamuş, 2013). OSB olan çocuklarda taklit becerilerinin, hem normal gelişim gösteren hem de gelişim geriliği olan çocuklara göre sınırlılık yaşanan bir alan olması (Rogers ve diğ., 2003; Stone, Ousley ve Littleford, 1997; Turan ve Ökcün-Akçamuş, 2013) taklit becerilerindeki sinırlılı̆̆ın OSB'nin belirgin özelliklerinden biri olduğunu göstermektedir. Charman ve diğerleri (1997), 20 aylık OSB olan çocukların, gelişim geriliği olan çocukların ve normal gelişim gösteren çocukların taklit becerilerini karşılaştırmışlar; sözel olmayan zeka yaşı kontrol altına alındığında OSB olan çocukların, hem normal gelişen hem de gelişim geriliği olan çocuklardan anlamlı derecede düşük taklit performansı gösterdiğini bulmuşlardır. Dawson ve diğerleri (1998), OSB tanılı, Down sendromlu ve normal gelişim gösteren çocukları alıcı dil zeka yaşlarına, iletişim puanlarına, Down sendromlu ve OSB olan çocukları kronolojik yaşlarına göre eşleştirmişler ve gruplar arası taklit davranışlarında farklılık olup olmadığını incelemişlerdir. Araştırmanın sonucunda OSB olan çocukların hem anında taklitte hem de ertelenmiş taklitte diğer gruplardan daha düşük performans gösterdiklerini bulmuşlardır. Hem Charman ve diğerlerinin (1997) hem de Dawson ve diğerlerinin (1998), araştırmalarında taklit becerilerini değerlendirirken yapılandırılmış ortamda bir nesneyle eylem yapmış ve nesneyi daha sonra taklit etmesi için çocuğa sunmuşlardır. 
OSB olan çocuklar, gelişimsel geriliği olan çocuklarla karşılaştırıldıklarında da taklit becerilerinde sinırlılıklar göstermektedir (Rogers ve diğ., 2003; Turan ve Ökcün-Akçamuş, 2013). Rogers ve diğerleri (2003), yaptıkları çalışmada 26-41 aylık OSB olan çocukların taklit gelişimlerini normal gelişen, gelişim geriliği olan (Down sendromu, kromozomal bozukluklar ve gelişimsel gecikmesi olan çocuklar) ve Fragile X sendromu olan çocuklar ile karşılaştırmışlar, OSB olan çocukların taklit beceri puanlarının tüm gruplardan anlamlı olarak daha düşük olduğunu bulmuşlardır. Stone, Ousley ve Littleford ise (1997), 26-36 ay arası OSB olan çocukların taklit becerilerini zeka yaşlarına göre eşleştirilmiş normal gelişen çocuklarla ve zeka yaşı ile kronolojik yaş ve ifade edici dil puanına göre eşleştirilmiş gelişimsel geriliği olan çocuklarla karşılaştıran bir çalışma yapmışlardır. OSB olan çocukların taklitte gelişimsel geriliği olan çocuklardan anlamlı derecede düşük performans gösterdiklerini ileri süren araştırmacılar, taklitte görülen sınırlılıkların otizme özel bir bozukluk olduğunu iddia etmişlerdir. Rogers ve diğerlerinin (2003), Stone, Ousley ve Littleford'un (1997) ve Turan ve Ökcün-Akçamuş’un (2013) çalışmalarında yapılandırılmış taklit işlemleri kullanılmış ve bu çalışmalarda nesneli taklit becerileri, motor taklit becerileri, oral motor taklit becerileri değerlendirilmiştir. Bu çalışmaların sonucunda OSB olan çocukların tüm taklit alanlarında sınırlılıklar gösterdikleri bulunmuştur. Stone, Ousley ve Littleford (1997), çocukların motor taklit becerilerinde, nesneli taklit becerilerinden ve oyuncak tarağı masada yürütmek gibi anlamsız nesneli taklitlerde, oyuncak köpeği masada yürütmek gibi anlamlı nesneli taklitlerinden daha fazla zorlandıklarını bulmuşlardır. Taklit becerilerinde görülen sınırlılıklar taklit türlerine göre incelendiğinde ise, OSB olan çocukların nesneli taklit becerilerinde, motor taklitlerden daha yüksek puan aldıkları, anlamsız nesne taklitlerinde, anlamlı nesne taklitlerine oranla daha fazla zorlandıkları görülmüştür.

OSB olan çocuklar, kendiliğinden taklit becerilerinde yapılandırılmış taklit becerilerinden daha düşük performans göstermektedirler (Ingersoll, 2008b; McDuffie ve diğ., 2007). Ingersoll (2008b), sözel olmayan zeka yaşlarına göre eşleştirilmiş normal gelişen çocuklar ile OSB olan çocukların, yapılandırılmış ortamda yapılandırılmış taklit becerileri ile doğal ortamda kendiliğinden taklit becerilerini karşılaştıran bir araştırma yapmıştır. Araştırmanın sonucunda, OSB olan çocukların her iki taklit türünde de normal gelişen çocuklardan daha düşük bir performans gösterdikleri bulunmuştur. OSB olan çocukların taklit türlerine göre performansları incelediğinde ise kendiliğinden taklit becerilerinde daha fazla güçlük yaşadıkları, bunun aksine normal gelişen çocukların her iki taklit türünde de benzer performans gösterdikleri bulunmuştur. Yapılandırılmış taklit ile kendiliğinden taklit becerileri farklı yeterlilikleri gerektirmektedir. Yapılandırılmış taklit işlemleri ile çocuk, kişisel bir amaç olmadan gözlemlediği eylemi yeniden üretmektedir. Taklidin çocuğun kendi isteği ile yapıldığ1 ve ortaya çıktığı durumlarda ise, çocuk çevresinde bulunan bütün davranış modellerinden kendi motivasyonu ile eşleşen birini seçmektedir (Nadel ve Aouka, 2006). OSB olan çocukların kendiliğinden taklit becerilerinde, yapılandırılmış taklit becerilerinden daha fazla zorlanması, Quill'in (2002) OSB olan çocukların sadece eylemi taklit ettiği, eylemin içeriğini anlamakta sınırlılıkları olduğu yönündeki yorumunu desteklemektedir. Rogers ve Pennington (1991), taklidin duyguların paylaşımının ve zihin kuramının erken sosyal yeterliliğini oluşturduğunu öne sürmektedir. Bebekler, iletişim amaçlı neyi ve nasıl taklit edeceklerine karar verirken, gözlemledikleri bireylerin bağlam içinde amacını ve niyetini anlayarak ve davranışı yorumlayarak seçim yapmaktadırlar. Normal gelişim gösteren bebekler, gözlemledikleri davranışı ya da davranışın sonuçlarını basitçe tekrar üretmezler, gözlemlenen bireyin davranışını amaca yönelik olarak görürler ve bu süreçte tekrar edecekleri davranışı seçerler, uyum sağlarlar ve kendi davranışlarını da adapte ederler. Model alırken gözlemlenen bireyin amaçlı olmayan davranışlarını ayırabilirler ve aynı sonuca yönelik yeni davranışlar ortaya koyabilirler ya da tamamlanmamış, sonucunu gözlemleyemedikleri bir davranışın sürecini taklit ederek ortaya çıkabilirler. Bütün bu davranışlar ortak dikkat bağlamı içinde gerçekleşmektedir (Carpenter, 2006).

Sonuç olarak araştırmalar OSB olan çocukların taklit becerilerinde hem normal gelişim gösteren hem de gelişimsel geriliği olan çocuklardan daha düşük performans gösterdiklerini ve kendiliğinden taklit becerilerinde OSB olan çocukların yaşadıkları güçlüklerin daha da arttığını göstermektedir. Taklit becerileri erken dönem sosyal iletişim becerilerinden biridir ve iletişimsel bir eylem olmakla birlikte (Dawson ve Galpert, 1986), sosyal öğrenme için de gerekli bir beceri olarak kabul edilmektedir (Ingersol, 2008a; Nadel, 2006). Taklidin erken dönem bir sosyal iletişim becerisi olması ve dil gelişimi ile arasındaki ilişki (Stone, Ousley ve Littleford, 1997; 
Toth, Munson, Meltzoff ve Dawson, 2006; Turan ve Ökcün-Akçamuş, 2013) OSB olan çocuklarda taklit becerilerinde yaşanan sınırlılıkların dil gelişimi açısından önem taşıdığını göstermektedir. OSB olan çocuklarda görülen taklit problemlerinin, sosyal ilişki kurma ve bu sosyal ilişkiler içinde öğrenme sürecindeki başlica engellerden biri olduğu düşünülmektedir (Dawson ve Galbert, 1986).

\section{OSB Olan Çocuklarda Oyun Gelişimi}

Oyun, oyunu oynayan kişi için eğlenceli ve keyif verici olan, içsel bir motivasyonla gerçekleştirilen, dışsal bir hedef içermeyen, oyuna katılan bireylerin aktif katılımı ile kendiliğinden ve gönüllü biçimde ortaya konulan etkinliklerdir (Garvey, 1990). Oyun çocukların bilişsel, fiziksel, sosyal ve duygusal gelişimlerine katkılarından dolayı çocuk gelişiminde önemli bir yere sahiptir (Ginsburg, 2007). Lifter ve Bloom (1998), oyunun çocuk için iki işlevi olduğunu öne sürmüştür. Bunlardan birincisi dile benzer biçimde, çocukların zihinlerinde ne olduğuna ilişkin sembolleri somutlaştırması ve ortaya koyması için kullanabileceği yollardan biri olmasıdır. Dolayısı ile oyun çocuğun kendini ifade biçimlerinden biridir. İkincisi, oyunun çocuklar için kendi eylemlerinin sonuçlarını yorumlayarak ve daha önceki bilgilerini gözden geçirerek çevrelerindeki nesneleri, olayları ve ilişkileri öğrenmelerinde bir araç olması, dolayısı ile yorumlama işlevi olmasıdır. Tüm bunlarla birlikte oyun aynı zamanda çocukların çevrelerindeki dünyaya ilişkin ne bildiklerini gösterme yollarından biridir. Oyun gelişimi, sembolik anlamanın yanı sıra nesnelerin nasıl çalıştığını ve eylemlerin sonuçları nasıl etkilediğini anlamada, bireylerin belirli durumlarda nasıl davrandıklarını ve kişiler arası ilişkileri anlama süreçlerinde önemlidir (Moor, 2002).

Bebek ve ebeveyn doğumdan itibaren karşılıklı oynamaya başlarlar. Bebekler, 6 haftalık olduklarında oyun başlatma davranışı gösterebilirler. Sosyal oyunlara adapte olma becerileri ortalama 13. haftada gelişir ve bebekler bu dönemde oyuna başlamaya hazır olduklarının sinyallerini verirler (Owens, 2012). Çocuğun bilişsel gelişimine bağlı olarak, oyun gelişimi de evrelere ayrılmaktadır. Piaget (1951), çocuklarda oyunun bilişsel gelişim ile ilişkili olduğunu öne sürmüş ve oyun gelişimini 1) alıştırma oyunları, 2) sembolik oyun ve 3) kurallı oyunlar olmak üzere üç gelişimsel aşama içinde ele almıştır. Piaget'e göre alıştırma oyunları, çocuklarda erken dönemlerde gelişen nesneleri keşfetmeye yönelik, vurma atma gibi davranışlarla ortaya konulan duyu-motor oyunlar olarak ele alınabilir. Piaget'e göre alıştırma oyunlarından sonra gelişen sembolik oyun ise, çocuğun çevresindeki nesneler için zihninde temsiller oluşturmaya başlamasıyla yani bilişsel olarak sembolik düşünmenin gelişmesi ile ortaya çıkan bir oyun çeşididir (akt., Smith, 2010). Sembolik oyun nesneleri başka bir nesnenin yerine kullanma, nesneye yeni özellikler ekleme (bebeği hasta etmek vb.) ve oyunda var olmayan bir şey için varmış gibi yapma olmak üzere üç biçimde ortaya konulabilmektedir (Leslie, 1987). Üçüncü gelişimsel oyun aşaması olan kurallı oyunlar ise, önceden belirlenmiş kurallar çerçevesinde oynanan futbol ve saklambaç gibi oyunlardir (Smith, 2010).

OSB olan çocuklar, sosyal ve bilişsel gelişimlerinde ve dil yeterliliklerindeki bireysel farklılıklarla ilişkili olarak, oyun gelişimlerinde de birbirlerinden farklı özellikler göstermektedirler (Wolfberg, 1994). Stone ve diğerleri (1990), OSB olan, zihin engelli, işitme engelli, dil bozukluğu olan ve normal gelişim gösteren çocukların oyun ve taklit davranışlarını karşılaştıran çalışmalarında, OSB olan çocukların tüm gruplardan daha az oranda oyuncaklarla etkileşime girdiklerini bulmuşlardır. OSB olan çocukların, oyuncakları amacına uygun kullanma, işlevsel oyun eylemlerinde bulunma davranışlarında da diğer gruplardan daha düşük performans gösterdiklerini bulmuşlardır. Araştırmacılar, taklit ve işlevsel oyun davranışlarının OSB olan çocukları diğer gruplardan ayırt ettiğini belirlemişler ve oyun becerilerindeki ve taklit gelişimindeki sınırlılıkların OSB'ye özgü davranışlar olduğunu öne sürmüşlerdir. OSB olan çocuklar, normal gelişen akranlarına göre sıra dışı oyun tercihlerinde bulunabilmekte veya oyunda kullanılan nesnenin belirgin bir özelliği ile aşırı ilgilenebilmektedirler. Doğal olarak OSB olan çocukların oyun davranışları çeşitliliği, esnekliği ve yaratıcılığı zayıf oyun eylemlerinden oluşmaktadır (Baranek, 1999; Baranek, Reinhartsen ve Wannamaker, 2001).

OSB olan çocuklarda nesne kullanma davranışları üzerine yapılan bir çalışma ile Rowland ve Schweigert (2009), 2-5 yaş arası OSB olan çocukların nesnenin sosyal kullanımı, sembolik kullanımı, 
ulaşılamayan bir nesneyi elde etme davranışları ve nesnenin işlevine uygun kullanımı davranışlarında normal gelişen akranlarından daha düşük performans gösterdiklerini, özellikle nesnenin sembolik kullanımı ile sosyal kullanımı davranışlarında düşük puanlar aldıklarını bulmuşlardır. Bunun yanı sıra OSB olan çocukların nesneleri kullanırken normal gelişen çocuklara oranla daha fazla tekrarlayıcı davranış sergilemektedirler (Richler, Bishop, Kleinke ve Lord, 2007). OSB olan çocukların, yaşamlarının ilk yıllarında normal gelişen çocuklardan daha çok nesneleri ağzına alma davranışları gösterdikleri geriye dönük video analizlerin incelenmesi ile ortaya konulmuştur (Baranek, 1999). Geriye dönük video kayıtların analizi ile yapılan başka bir çalışmada Baranek ve diğerleri (2005), OSB olan çocukların 9-12 ay arasındaki nesne ile oyunlarını normal gelişen ve gelişimsel geriliği olan çocuklarla karşılaştırmışlardır. Bu araştırmada OSB olan çocuklarla diğer grupların nesne ile ilgilenme oranları arasında anlamlı bir farklılık olmadığı bulunmuştur. Daha da önemlisi keşfedici oyun oranları arasında da anlamlı bir farklılık olmadığı bulunmuştur. Araştırma sonuçlarına göre, 9-12 ay arasında sadece normal gelişen çocuklarda nesne ile işlevsel oyun oynama davranışı ortaya çıkmış, diğer iki grupta işlevsel oyun davranışları gözlenememiştir. Çocukların çevrelerindeki nesnelerle etkileşimleri, onların sosyal dünyayı anlamalarını ve istenilen sonuca ulaşmak için nesneleri nasıl kullanacakları hakkındaki bilgilerini yansıtır. Nesne ile etkileşim davranışları sadece nesnenin fiziksel olarak manipülasyonunu içermez, aynı zamanda nesne ile etkileşime giren bireyin nesnelerin nasıl kullanıldığı, istenilen nesneye ulaşmak için hangi yolları kullanacağını, nesneler arasında ilişki ve birey ve nesne arasındaki ilişkiye dair bilgilerini de gösterir. Nesne ilişkileri, normal gelişen çocuklarda en çok nesne ile oyun davranışları ile ortaya çıkar ve çocuğun bilişsel ve sosyal gelişimine önemli katkılarda bulunur (Rowland ve Schweigert, 2009).

OSB olan çocuklarda, nesne kullanımlarının yanı sıra oyun gelişiminde erken yaşlardan başlayarak sinırlılıklar görülmektedir (Charman ve diğ., 1997; Wetherby, Watt, Morgan ve Shumway, 2007). OSB olan çocuklarda 18-24. aylar arasında sembolik becerilerde ya da temsili düşünme yeterliliklerinde sınırlılıklar görülmektedir (Wetherby ve diğ., 2007). OSB olan çocukların iletişim davranışlarını inceleyen çalışmalarında Charman ve diğerleri (1997), 20 aylık OSB olan çocukların normal gelişen çocuklara oranla daha sınırlı oranda mış gibi oyun sergilediklerini, işlevsel oyun davranışlarında ise üç grup arasında anlamlı bir farklılık olmadığını bulmuşlardır. Araştırmacılar bu çalışmanın sonucunda, oyunda görülen bozuklukların sadece sembolik oyun davranışları ile ilişkili olduğunu öne sürmüşlerdir. Çalışmada OSB olan çocukların, model olunan ve ipucu verilen durumlarda bile bir nesneyi başka bir nesne yerine sembolik kullanmada sınırlılıklar gösterdiklerini bulmuşlardır. Wetherby ve diğerleri (2007) ise, 18-24. ay arasında gelişimsel geriliği olan ve OSB olan çocukların her ikisinde de normal gelişen çocuklarla karşılaştırdıklarında sembolik becerilerinde ve temsili nesne kullanma yeterliliklerinde anlamlı olarak düşük performans gösterdiklerini bulmuşlardır. OSB olan çocukların, sembolik oyun becerilerinde yaşadıkları sınırlılıklar yapılan birçok çalışma ile ortaya konulmuştur (Brown ve Whiten, 2000; Charman ve Baron-Cohen, 1997; Hobson, Lee ve Hobson, 2009; Libby, Powell, Messer ve Jordan 1998; Sigman ve Ungerer, 1984; Williams, Reddy ve Costall, 2001). Libby ve diğerleri (1998), OSB olan çocukların spontan olarak oyuna katılma davranışlarını sözel gelişim düzeyine göre eşleştirilmiş Down sendromlu ve normal gelişim gösteren çocuklarla karşılaştırarak inceledikleri araştırma sonucunda, OSB olan çocukların diğer iki gruba oranla sembolik oyun oynamada sınırlılıklar yaşadıklarını, özellikle sembolik oyun eylemi sayıları göz önüne alındığında bu farklılığın daha açık görüldüğünü bulmuşlardır. İşlevsel oyun davranışları arasında ise anlamlı bir farklılık olmadığı, bununla birlikte diğer gruplara göre daha fazla duyu motor oyun sergiledikleri görülmüştür. Williams ve diğerleri (2001), OSB olan çocukların akranları ile aynı oranda işlevsel oyun sergilemelerine rağmen oyunun niteliğine ilişkin ciddi farklılıklar olduğunu öne sürmüştür. Araştırmalarında OSB olan çocuklarda oyunun, özellikle oyun şemalarının çeşitliliği, ayrıntılı olması ve birbirini tamamlayıcı olması bakımından sınırlı olduğunu bulmuşlardır. OSB olan çocuklarda, sözel dil performansı ve oyun seviyesine göre eşleştirildikleri gelişimsel geriliği olan çocuklara göre sembolik oyun davranışlarında, kendilerinin oyunda anlam yarattıklarının farkında olmama, oyuna daha az eğlenceli -mış gibi şemalar katma, sembolik anlamlar yaratmama, ve genel olarak yaratıcı ve eğlenceli oyun kurma niteliklerinde sinırlılıklar bulunmaktadır (Hobson ve diğ., 2009.) 
Sonuç olarak alanyazın incelendiğinde, OSB olan çocukların oyun becerilerinde küçük yaşlardan itibaren sınırlılık yaşadıkları, özellikle sembolik oyun becerilerinde normal gelişim gösteren ve gelişimsel geriliği olan çocuklardan daha düşük performans gösterdikleri görülmektedir. Sembolik oyun becerilerinin dil gelişimi ile ilişkili olması (Smith, Miranda ve Zaidman-Zait, 2007; Toth ve diğ., 2006) nedeniyle OSB olan çocuklarda sembolik oyun becerilerinde yaşanan sınırll1ıkların dil gelişiminde önemli bir rolü olabileceği düşünülmektedir.

\section{OSB Olan Çocuklarda Ortak Dikkat Gelişimi}

Ortak dikkat, basitçe iki ya da daha fazla bireyin aynı dışsal uyaran üzerine aynı anda odaklanması olarak tanımlanabilir (Baldwin, 1995). İlk yılın ortalarında bebeklerin yetişkin ile etkileşimlerine çevreden nesneleri dahil etmeleri ile bu bilgi ortaya çıkmaya başlar. Bebeklerin gelişimin erken dönemlerinde dışsal bir nesneyi yetişkin ile etkileşime dahil etmeye başlaması üç şekilde ortaya çıkmaktadır: 1) dikkati paylaşma, 2) dikkati izleme ve 3) dikkati yöneltme. Bu üç davranış, ikili (dyadic) etkileşimden, üçlü (triadic) etkileşime geçişi işaret etmektedir ve bu davranışların temel özelliği, bebeğin nesne ve yetişkin arasında bakışının yönünü değiştirmesi ve yetişkinin bir nesneye tepkisini izlemek için yeniden yetişkine bakmasıdır (Carpenter ve diğ., 1998). Tomasello (1995), ortak dikkatin yalnızca iki insanın aynı zamanda aynı yere bakması ya da bir birey bir nesne ile etkileşim içinde iken diğer bireyin onu izlemesi olarak ele alınamayacağını ifade etmiştir. Tomasello'ya göre ortak dikkat bağlamında çocuk, ilgi odağını nesne ve bireye koordine ederken aynı zamanda yetişkin de aynı nesne ve çocuk üzerine dikkatini koordine eder. Hem çocuk hem de yetişkinin ilgisini koordine etmesi ortak dikkatin en önemli bileşenidir. Ortak dikkat etkileşimindeki koordineli dikkat, bireyin etkileşimdeki diğer bireyin aynı varlık üzerinde ilgisini odakladığını anlaması üzerine kuruludur. Koordineli dikkat, çocuğun etkileşimde yer alan diğer katılımcıyı bir nesne olarak değil, kendisi gibi çevresindeki belirli olaylara dikkatini veren bir birey olarak anladığına işaret eder.

Ortak dikkat davranışları, yetişkinin gösterdiği ya da yetişkinin baktı̆̆ı yere bakmak gibi ortak dikkati yanıtlama ve ilgisini çeken bir oyuncağa bakmak, ardından yetişkinin gözlerine bakarak ve oyuncağı göstermek gibi ortak dikkat başlatma olmak üzere iki işlevsel kategoriye ayrılmaktadır. Ortak dikkati yanıtlama, bebeğin ortak odağı paylaşmak amaçlı diğerlerinin jestlerini ve bakış yönünü izlemesi olarak tanımlanabilir. Ortak dikkat başlatma ise bireyin, çevresindeki kişilerin dikkatini kendisine, nesnelere ya da olaylara yönlendirmek için jestler ve bakışlarını kullanması olarak tanımlanmaktadır. Ortak dikkat başlatma, diğer bireylerle deneyimleri ve ilgileri paylaşma işlevi ile ortaya çıkmaktadır (Mundy ve Jarrold, 2010). Temel olarak ortak dikkat başlatma ve yanıtlama davranışlarının başlaması, bebeklerin çevresindeki yetişkinin ve diğer bireylerin kendisi gibi amaçlı varlıklar olduğunu, kendisi gibi dikkatini paylaşabilecek ya da dikkati yönlendirilebilecek varlıklar olduğunu anlamasına işaret etmektedir (Carpenter ve diğ., 1998). Bu kişiler arası gerçek bir paylaşımdır ve gelişimde önemli bir role sahiptir (Tomasello ve Carpenter, 2007). Normal gelişim gösteren çocuklarda ortalama 9. ayda ortak dikkat bağlamına katılım, 10.5. ayda nesneyi manipüle ederek ortak dikkat başlatma, 11. ayda yetişkinin işaret ettiği yere bakarak ortak dikkati yanıtlama ve 12. ayda işaret ederek ortak dikkat başlatma becerileri ortaya çıkmaya başlamaktadır (Carpenter ve diğ., 1998).

OSB olan çocuklar ile normal gelişen çocuklar arasında, özellikle iletişim amacı bir nesne hakkında ilgiyi ya da dikkati paylaşmak olduğunda, iletişim amaçlı jest kullanımlarında belirgin farklılıklar ortaya çıkmaktadır (Camaioni ve diğ., 2003). OSB olan çocuklarda görülen iletişim bozukluklarından birinin, ortak dikkat davranışlarının kazanılmasında yaşanan güçlüklerle ortaya çıktığı söylenebilir. Sınırlılık yaşanılan ortak dikkat becerileri kapsamında; deneyimlerini diğer bireylerle paylaşmak amacı ile jestlerin kullanılmasında, göz kontağının kullanılmasında, bakışın yönünü değiştirmede bozukluklar görülmektedir (Mundy ve Markus, 1997). OSB olan çocuklarda ortak dikkat becerilerinde görülen bu bozukluklar, jestler gibi OSB'nin erken dönem tanı özelliklerinden biridir (Thurm, Bishop ve Shumway, 2011).

Dawson ve diğerleri (2004), ortalama 43 aylık OSB olan çocukların sosyal oryantasyon, ortak dikkat ve diğer bireylerin rahatsız olma durumlarına dikkat gibi sosyal davranışlarını zeka yaşlarına göre eşleştirilmiş, 
normal gelişen ve gelişim geriliği olan çocuklarla (Down sendromu ve gelişimsel gecikmesi olan çocuklar) karşılaştırmışlardır. Araştırmanın sonucunda OSB olan çocukların bütün değişkenlerde normal gelişim gösteren ve gelişim geriliği olan gruplara göre anlamlı derecede düşük performans gösterdikleri bulunmuştur. Araştırmada OSB tanılı çocuklar, hem normal gelişen hem de gelişim geriliği olan çocuklardan anlamlı derecede daha az ortak dikkat başlatma ve yanıtlama davranışı sergilemişlerdir. Gelişim geriliği olan çocuklar ile normal gelişen çocukların ortak dikkat başlatma ve yanıtlama davranışları arasında ise anlamlı bir farklılık görülmemiştir. Araştırmanın sonucunda ortak dikkatin tek başına OSB olan çocukları \%83 oranında doğru sınıfladığı bulunmuş dolayısı ile ortak dikkat davranışlarının, tek başına OSB olan ve olmayan çocukları yüksek bir oranda ayırt ettiği öne sürülmüştür. Ortak dikkat alanında yaşanan sınırlılıkların OSB olan bireyler için ayırt edici özellik olduğunu bulan boylamsal bir çalışma da Sigman ve Ruskin (1999) tarafından yapılmıştır. Sigman ve Ruskin'in yaptıkları araştırmanın sonucunda, ortak dikkat başlatmada ve yanıtlamada, sembolik oyunun bazı biçimlerinde, diğerlerinin duygusal durumlarına tepki vermede ve akranlarla etkileşim başlatma davranışlarında OSB olan çocukların kendi tanı grubuna özgü sınırlılıklar gösterdikleri bulunmuştur. Araştırmanın sonucunda elde ettikleri bulguların 1şığında araştırmacılar, ortak dikkat davranışlarının OSB olan çocukların özgün ve diğer gruplardan farklı biçimde sorun yaşadıkları bir alan olduğunu iddia etmişlerdir.

OSB olan çocuklarda bozukluğun semptomları, normal gelişen çocuklarda ortak dikkat gelişiminin başladığı dönemle aynı dönemde görülmeye başlamakta (Thurm ve diğ., 2011) ve OSB olan çocuklarda hem ortak dikkat başlatma hem de ortak dikkati yanıtlama becerilerinde sinırlılıklar görülmektedir (Sigman ve Ruskin, 1999). Wetherby ve diğerleri (2007), OSB olan çocukların 18-24 ay arası sosyal gelişim davranışlarını incelediklerinde, OSB olan çocukların ortak dikkati yanıtlama (bakılan ve gösterilen yeri izleme), iletişim sıklığ ve ortak dikkat başlatma davranışlarında normal gelişen ve gelişim geriliği olan akranlarından anlamlı derecede düşük performans gösterdiklerini, nesne ve yetişkin arasında bakışı değiştirme davranışları oranının da iki gruptan daha düşük olduğunu bulmuşlardır. Ortak dikkatte yaşanan bu sınırlılığın OSB'ye özgü bir bozukluk olduğu öne sürülmektedir (Shumway ve Wetherby, 2009). Kronolojik yaşı daha büyük çocuklarla bir çalışma yapan Lewy ve Dawson (1992), 37-70 aylık okul öncesi OSB tanılı çocukların alıcı dil performanslarına göre (ortalama 20-22 ay) eşleştirilmiş normal gelişen ve Down sendromlu çocuklarla ortak dikkat başlatma davranışlarını karşılaştırmışlar ve diğer araştırmalarla benzer olarak OSB olan çocukların ortak dikkat başlatma davranışlarında her iki gruptan düşük performans gösterdiğini bulmuşlardır. Bu araştırmalardan da görüldüğü üzere ortak dikkat alanında yaşanan sıkıntılar OSB olan çocuklarda gelişimin erken dönemlerinde görülebilmekte, gelişimin ilerleyen dönemlerinde de devam etmekte ve OSB olan çocukları normal gelişen ve gelişim geriliği olan çocuklardan ayırt edebilmektedir.

OSB olan çocuklarda hem ortak dikkat başlatma hem de ortak dikkati yanıtlama davranışlarında gelişimin erken dönemlerinde sinırlılıklar görülmektedir (Lord ve diğ., 2000; Stone, Coonrod ve Ousley, 2000). Ortak dikkat yanıtlama erken dönemlerde OSB olan çocuklar için ayırt edici bir özellik iken gelişimin ilerleyen dönemlerinde ortak dikkati yanıtlamada görülen güçlükler azalmaya başlamaktadır (Mundy ve Jarrold, 2010). Mundy, Sigman ve Kasari (1994), çalışmalarında bilişsel gelişim evresi 30-36 ay arasında OSB olan çocuklarda ortak dikkat yanıtlama becerilerinin ayırt ediciliğinin düştüğünü bulmuşlardır. Otizm Tanı Gözlem Ölçeği’nde de (Autism Diagnostic Observation Schedule, ADOS) Modül 1'de ortak dikkati yanıtlama ve başlatma tanı ölçütleri içinde yer alırken, Modül 2'de sadece ortak dikkati başlatma tanı ölçütleri içinde yer almaktadır. Modül 1, tutarlı biçimde sözel ifade kullanmayan çocukları değerlendirirken; Modül 2, sözel ifade kullanan fakat akıcı biçimde sözel ifade üretmeyen çocuklar için kullanılmaktadır (Lord ve diğ., 2000). Ortak dikkat başlatma alanında yaşanan sınırlılıklar, kronolojik yaşın ve zeka yaşının büyümesi ile de devam etmektedir (Leekam, Baron-Cohen, Perrett, Milders ve Brown, 1997). Hobson ve Hobson (2007), çalışmalarında kronolojik yaşları ortalama 11,5, sözel zeka yaşları ise ortalama 6 olan OSB bozukluğu olan çocukların, kronolojik yaşlarına ve dil performanslarına göre eşleştirildikleri farklı engel gruplarındaki çocuklardan (öğrenme güçlüğü olan, zihinsel engeli olan, gelişimsel gecikme gösteren çocuklar) daha az ortak dikkat başlatma davranışı sergilediklerini bulmuşlardır. $\mathrm{Bu}$ bulgu OSB olan çocuklarda, yaş ve dil performansları artmakla beraber ortak dikkat başlatmada yaşanılan sınırlılıkların devam ettiği tezini desteklemektedir. 
Sonuç olarak OSB olan çocukların ortak dikkat alanında güçlükler yaşadıkları araştırma bulguları ile desteklenmektedir. Alanyazın göz önüne alındığında ortak dikkat becerilerinde yaşanan güçlüklerin OSB'ye özgü olduğu ve otizmin ayırt edici özeliklerinden biri olduğu söylenebilir. OSB olan çocuklarda ortak dikkat erken dönem tanı göstergelerinden biri olarak ele alınmaktadır. Ortak dikkati başlatma ve yanıtlama davranışlarının her ikisi de erken çocukluk döneminde tanılama için önemli davranışlar iken gelişimin ilerleyen dönemlerinde ortak dikkat yanıtlama becerilerinde yaşanan güçlükler azalmakta, ortak dikkat başlatma becerilerinde ise güçlükler yaşanmaya devam etmektedir. Ortak dikkat becerilerinin bir erken dönem sosyal iletişim becerisi olması (Carpenter ve diğ., 1998) ve dil ile ilişkili olması (Bono, Daley ve Sigman, 2004; Dawson ve diğ., 2004; Toth ve diğ., 2006) nedeniyle ortak dikkat becerilerinde yaşanan sınırlılıkların OSB olan çocukların dil ve iletişim gelişiminde önemli bir yeri olduğu düşünülmektedir.

Alanyazında yapılan çalışmalar, OSB olan çocukların, jestler, taklit, sembolik oyun ve ortak dikkat becerilerini içeren sözel olmayan sosyal iletişim becerilerinde normal gelişim gösteren ve gelişimsel geriliği olan çocuklara oranla güçlükler yaşadıklarını ve bu iletişim becerilerinin her birinin genel dil gelişimi ile ilişkili olduğunu göstermektedir. OSB olan çocuklarda görülen iletişim bozukluklarının bir yönünü sözel olmayan sosyal iletişim becerilerinde yaşanan sınırl1lıklar oluştururken, diğer yönünü dil gelişiminde görülen sınırl1lıklar oluşturmaktadır (APA, 2013). Araştırmanın ilerleyen bölümünde OSB olan çocuklarda dilin bileşenlerine göre sözel dil gelişimi özellikleri ele alınacaktır.

\section{OSB Olan Çocuklarda Sözel Dil Gelişimi}

Normal gelişim gösteren çocuklarda sözel olmayan sosyal iletişim davranışlarının kazanılmasından kısa bir süre sonra ortalama 12. ayda ilk sözcükler ortaya çıar ve sözel dil dönemi başlar. Çocuklar, söz öncesi dönemde sesler ve jestlerle ifade ettiği iletişim amacını, sözel dilin kazanılmaya başlaması ile birlikte jestlerin eşliğinde ya da jestler olmadan sözcüklerle ifade etmeye başlarlar (Owens, 2012). İlk sözcüklerin kazanımının ardından ortalama 18-30. aylar arası sözcükleri birleştirerek, 30-48. aylar arası basit cümleler ile ve ardından karmaşık cümleler ile kendilerini ifade ederler (Tager-Flusberg ve diğ., 2009).

OSB olan çocuklarda dil ve sosyal iletişim bozukluklarının geniş bir dağılımı vardır (Tager-Flusberg, 1999) ve bu bozukluklarla ilişkili olarak çocukların dil kazanım örüntülerinde de önemli farklılıklar bulunmaktadır (Kjelgaard ve Tager-Flusberg, 2001; Tager-Flusberg ve diğ., 2005). OSB olan bazı çocuklarda hiç konuşma görülmezken, bazı çocuklarda sadece ekolalik konuşma görülebilir ya da normal gelişen çocuklara yakın biçimde sözel dil performansı görülebilir (Owens, Evan-Metz ve Haas, 2003; Tager-Flusberg, 1999). Bu çeşitlilik bazen değerlendirilen çocuğun bilişsel gelişim seviyesi ve yaşı ile ilişkili olabilmekle beraber, her zaman böyle bir ilişki söz konusu olmamaktadır. OSB olan çocuklarda dil bileşenlerine göre incelendiğinde, dil ve iletişim bozukluklarında da farklı özellikler görülebilir (Tager-Flusberg, 1999). Dilin farklı bileşenlerine yönelik farklı gelişimsel özellikleri görüldüğü için OSB olan çocukların sözel dil gelişimi dilin bileşenlerine göre ele alınacaktır. Bu çalışmada OSB olan çocuklarda dile ilişkin biçimbirim bilgisi, sözdizimi, anlam bilgisi ve kullanım bilgisi gelişimleri ele alınmaktadır ve ilerleyen bölümde OSB olan çocuklarda bu bileşenlerin özellikleri ile ilgili bilgi verilmektedir.

\section{OSB Olan Çocuklarda Biçimbirim Bilgisi/Sözdizimi Gelişimi}

Biçimbirim bilgisi, sözcüklerin kendi içinde düzenlenmesi ile ilgilidir (Owens, 2012). Başka bir ifade ile biçimbirim bilgisi, sözcük yapıları ve dilbilgisel yapıları (ekleri) içerir (Hedge ve Maul, 2006). Sözcükler bir ya da daha fazla biçimbirimden oluşurlar. Biçimbirim, dilde anlamlı en küçük birimlerdir. Biçimbirimler kendi içlerinde bağımlı biçimbirim ve bağımsız biçimbirim olmak üzere ikiye ayrılırlar. Bağımsız biçimbirimler tek başına anlam ifade eden "at" gibi sözcüklerden oluşurken; bağımlı biçimbirimler "-lar", "-cı" gibi tek başına anlam ifade etmeyen ve yanına eklendikleri sözcükler ile anlam kazanan, eklendikleri sözcüğe dilbilgisel anlam katan biçimbirimlerdir (Owens, 2012). Sözdizimi ise cümle içinde sözcüklerin sıralanış1, cümle düzeni ve sözcük ilişkilerini düzenleyen kurallar sistemidir. Cümle yapısı sözdizimi kuralları ile şekillenir ve bu kurallar ile sözcük, sözcük öbeği, yan cümle sıralanışı ve sözcükler arası ilişki, sözcük sınıfları ve diğer cümle bileşenleri 
düzenlenir. Sözdizimi kuralları ile hangi sözcük sıralanışının kabul edilebilir ve dilbilgisel olarak uygun olduğuna, hangilerinin uygun olmadığına karar verilir (Owens, 2012).

OSB olan çocuklarda biçimbirim bilgisi gelişimi normal gelişim gösteren çocuklarla benzerlikler göstermekle birlikte bazı farklılıklar da görülebilmektedir (Kuder, 1997). Alanyazında, OSB olan çocuklarda biçimbirimlerin kazanımında bir bozukluk olmadığı, sadece bir gecikmeden söz edilebileceği yönünde (TagerFlusberg ve diğ., 1990) ve OSB olan çocuklarda bazı biçimbirimlerin kazanımında bozukluk olduğu yönünde (Bartolucci, Pierce ve Streiner, 1980) iki grup tartışma söz konusudur. OSB olan çocuklarda dilbilgisel bileşenlerin kazanımında sendroma özgü bir bozukluktan ziyade bir gecikme olduğunu öne süren Tager-Flusberg ve diğerleri (1990), OSB olan çocukları yaşlarına göre ve ortalama sözce uzunluklarına (OSU) göre eşleştirdikleri Down sendromlu çocuklarla karşılaştıran boylamsal bir çalışma yapmışlardır. Araştırmada katılımcı çocukların OSU'larının, sözcük dağarcığının ve sözdizimi karmaşıklığı indeksinin (Index of Productive Syntax) 12-26. aylar arasındaki gelişimi incelenmiştir. Araştırmanın sonucunda OSB olan çocukların, Down sendromu olan çocuklarla aynı gelişimsel süreci izlediğini ve bu sürecin normal gelişen çocukların dil gelişimi ile de benzer olduğunu bulmuşlardır. Araştırmacılar, dilbilgisel karmaşıklığın ve sözcük dağarcığının OSB olan çocuklarda temel sorunlu alanlardan biri olmadığını öne sürmüşlerdir. Araştırmanın ilgi çekici sonuçlarından biri, OSU'su üç ve üçün üstünde olan çocukların sözdizimi karmaşıklıklarının Down sendromlu olan çocuklara göre daha düşük olduğunun bulunmasıdır. Araştırmacılar bu durumu, OSB olan çocukların OSU'ları artmasına rağmen kendiliğinden konuşmalarında daha sınırlı dilbilgisel yapı kullanmaları ile ilişkilendirmişlerdir.

OSB olan çocukların kullandıkları dilin dilbilgisel yapısını inceleyen araştırmalar biçimbirim bilgisi gelişimi ile ilgili bilgi vermektedir. Bartolucci ve diğerleri (1980), yaptıkları çalışmada OSB olan çocukların biçimbirim kullanımını, sözel olmayan zeka yaşlarına göre eşleştirdikleri zihinsel engelli çocukların ve normal gelişen çocukların biçimbirim kullanımı ile karşılaştırmışlardır. Çalışmanın sonucunda, anadili İngilizce olan OSB'li çocukların özellikle article (a, the), yardımcı fiil, bağlaç, geçmiş zaman eki, geniş zaman üçüncü şahıs ekleri ve şimdiki zaman ekinde normal gelişen çocuklardan daha sık biçimbirim atma davranışı gösterdiklerini, fakat zihinsel engelli grup ile aralarında anlamlı bir farklılık olmadığını bulmuşlardır. OSB olan çocuklarda biçimbirim atma oranı ile sözdizimi karmaşıklığı arasında anlamlı bir ilişki bulamayan araştırmacılar, biçimbirim atmanın OSB olan çocuklarda genel bir dil gelişsim gecikmesine bağlı olmadığını, aksine özgün bir gecikmeden kaynaklanabileceğini öne sürmüşlerdir.

OSB olan çocukların dil gelişimlerinde kendi içinde alt gruplar olduğu öne sürülmektedir (Kjelgaard ve Tager-Flusberg, 2001; Roberts, Rice ve Tager- Flusberg, 2004). Roberts ve diğerleri (2004), 5-15 yaş arası OSB olan çocuklarda geniş zaman üçüncü tekil şahıs eki (say/s, do/es) ve geçmiş zaman eklerinin (rake/d), play/ed) dil gelişim alt gruplarına göre farklılaşıp farklılaşmadığını inceleyen bir araştırma yapmışlardır. Sözcük dağarcığı performanslarına göre OSB olan çocukları normal puan diliminde, sınırda ve düşük puan diliminde olmak üzere üç grupta ele almışlardır. Araştırmanın sonucunda, düşük dil puan diliminde olan OSB'li çocuklarda özgül dil bozukluğu olan çocuklarla benzer biçimde, hem geniş zaman üçüncü tekil şahıs hem de geçmiş zaman eklerinde ek atma ya da hiç ek kullanmama gibi sorunlar olduğunu bulmuşlardır. Normal puan dağılımında görünen çocukların daha az geçmiş zaman ve üçüncü şahıs geniş zaman eki hatası ve atması yaptıklarını, en fazla ek hatası ve atmayı ise en düşük sözcük dağarcığı grubunda olan çocukların yaptıklarını bulmuşlardır. Özgül dil bozukluğu olan çocuklardan farklı olarak, anlık ekolali ve geçmiş yanıtların tekrarlanması hataları görülmüştür. Araştırmacılar, bu durumun çocukların görevi ya da istenilen şeyi anlamakta güçlük yaşamalarına bağlı olabileceğini öne sürmüşlerdir. Araştırmacılar, OSB olan çocuklarda bazı ek atmaların, yapısal bir bozukluktan değil sohbet bağlamını anlayamamalarından kaynaklanabileceğini, dolayısı ile ek atma nedeninin kullanım bilgisi bileşeninde yaşanılan sıkıntılardan kaynaklı olabileceğini öne sürmüşlerdir.

OSB olan çocukların zaman eki kullanımlarını inceleyen Bartolucci ve Albers (1974), 3-6 yaş arası OSB olan çocukların, zihin engelli ve normal gelişen çocuklarla karşılaştırıldıklarında geçmiş zaman eklerine ilişkin görevlerde her iki gruptan daha düşük performans sergilediklerini bulmuşlardır. Araştırmacılar bu bulguyu, OSB olan çocuklarda biçimbirim gelişimindeki bozuklukların, zihin engelli çocuklarda görülen 
bozukluklardan farklı olduğu yönünde tartışmışlardır. Çalışmaların tümüne genel olarak bakıldığında, OSB olan çocuklarda geçmiş zaman eki kullanımında bozukluklar olduğu (Bartolucci ve diğ., 1980; Bartolucci ve Albers, 1974; Roberts ve diğ., 2004), ve bu bozukluğun özgül dil bozukluğu olan çocuklarla benzerlikler taşıdığı görülmektedir (Roberts ve diğ., 2004). Bununla birlikte söz edilen çalışmaların bulgularının aksine Eigsti, Bennetto ve Dadlani (2007), sözel olmayan zeka yaşlarına, cinsiyetlerine ve alıcı sözcük performanslarına göre eşleştirildiklerinde gelişimsel geriliği olan çocuklarda daha fazla biçimbirim atma davranışı görüldüguünü, OSB olan çocuklar ile normal gelişen çocuklar arasında anlamlı bir farklılık olmadığını bulmuştur.

OSB olan çocukların diğer biçimbirim bilgisi hatalarına genel olarak bakıldığında, sıklıkla zamirlerde ve fiil eklerinde yanlış kullanımlar yaptıkları görülmektedir (Owens 1999). OSB olan çocuklarda görülen yanlış zamir kullanımları, dilin kullanım bilgisine ilişkin bir özellik olan sohbet sırasında dinleyici ve konuşmacı rollerinin değişmesi ile ilgili bir bozukluk olarak açılanabilmektedir (Tager-Flusberg ve diğ., 2005).

Sözdizimi, OSB olan çocuklarda görece güçlü gelişen alanlardan biri olarak düşünülmekle beraber (McGregor ve diğ., 2012), OSB olan çocukların sözdizimi gelişiminde de sınırlılıklar yaşadıkları görülmektedir (Rapin ve Dunn, 2003). OSB olan çocuklarda yüzeysel cümle kurma, yaşa göre daha az karmaşıklıkta cümle kurma gibi sözdizimi özellikleri görülmektedir (Owens, 1999). Bu sınırlılıklar genellikle sözdizimi gelişiminde gecikme ile kendini gösterirken sözdizimi, OSB olan çocukların dil ve iletişim gelişiminde temel sorunlu alanlardan biri olarak düşünülmemektedir (Rapin ve Dunn, 2003). OSB olan çocukların sözdizimi gelişimi, genellikle genel gelişimsel düzeyleri ile ilişkili olarak yavaş gelişme gözlenen bir alandır. OSB olan çocuklarda sözdizimi gelişiminin kronolojik yaşla paralel olarak karmaşıklaşmasından söz etmek mümkün değildir. Sözdizimi daha çok gelişimsel düzeyle ilişkili görünmektedir (Tager-Flusberg ve diğ., 2005). Pierce ve Bartolucci (1977), ortalama 10 yaşlarında olan OSB olan çocukların sözdizimi yeterliliklerini sözel olmayan zeka yaşlarına göre (ortalama 6 yaş) eşleştirilmiş zihinsel engel tanılı ve normal gelişen çocuklarla karşılaşıırmıştır. Araştırma sonucunda OSB olan çocukların, sözel olmayan (dile dayalı olmayan) zeka yaşlarına göre eşleştirildiği iki gruptan da daha düşük sözdizimini puanı aldıklarını bulmuşlardır. Sonuç olarak araştırmaya katılan OSB olan çocuklar, kendi sözel olmayan zeka yaşlarına göre düşük sözdizimi puanları almışlardır. Araştırmacılar, OSB olan çocukların sözdizimi ve biçimbirim kazanımlarının kurallara dayalı olduğunu fakat sözel olmayan zeka yaşlarına göre eşleştirildikleri zihinsel engelli ve normal gelişen çocuklara göre daha az karmaşık yapılar kullandıklarını öne sürmüş̧erdir. Sonuç olarak OSB olan çocukların sözdizimi gelişiminde, sözel olmayan zeka yaşlarına göre eşleştirildiklerinde gelişim geriliği olan ve normal gelişen çocuklarla karşılaştırıldığında anlamlı gecikmeler bulunmaktadır (Eigsti ve diğg., 2007). Eigsti ve diğerleri (2007), çalışmalarında ortalama 5 yaşında olan OSB'li çocukların sözel olmayan zeka yaşlarına, cinsiyetlerine ve alıcı sözcük dağarcıklarına göre eşleştirildiklerinde normal gelişen çocuklara oranla ve kronolojik yaşa, cinsiyete, sözel olmayan zeka yaşına ve alıcı sözcük dağarcığına göre eşleştirildiklerinde gelişimsel geriliği olan çocuklara oranla daha az karmaşık cümle kullandıklarını bulmuşlardır. Bu bulgular sözdizimindeki gecikmenin alıcı sözcük dağarcığından bağımsız olduğunu düşündürmektedir. Araştırmacılar, bu bulgunun OSB olan çocukların sözdizimi gelişiminde normal gelişen çocuklardan farklı bir yön izlediklerini gösterebileceğini öne sürmüşlerdir. Bu bulguların aksine Weismer ve diğerleri (2011), OSB olan çocukları ifade edici sözcük dağarcığına göre eşleştirip, çocukların sözel olmayan bilişsel yeterliliklerini kontrol altına aldıklarında, cümle karmaşıklığında dil gecikmesi olan çocuklarla bir farklılık olmadığını bulmuşlardır. Bu araştırmaya katılan çocukların kronolojik yaşlarının 22-37 ay olması nedeni ile karşılaştırmada erken dönem dilbilgisel yapılar (cümle biçimleri) kullanılmıştır.

Sonuç olarak alanyazında OSB olan çocuklarda biçimbirim bilgisi gelişimine ilişkin bir bozukluk olduğunu öne süren (Bartolucci ve diğ., 1980) ve bozukluktan ziyade biçimbirimlerin kazanımında bir gecikmeden söz edilebileceğini iddia eden (Tager-Flusberg ve diğ., 1990) iki grup tartışma vardır. OSB olan çocuklarda dilin kullanım bilgisi ve anlam bilgisi bileşenleri göz önüne alındığında biçimbirim bilgisi ve sözdiziminde görece iyi bir gelişim olduğu söylenebilir. Bununla birlikte normal gelişim gösteren çocuklar göz 
önüne alındığında biçimbirim bilgisi gelişiminde ve özellikle sözdizimi gelişiminde gelişimsel bir gecikmeden söz edilebilir.

\section{OSB Olan Çocuklarda Anlam Bilgisi Gelişimi}

Anlam bilgisi (semantik), bir dildeki sözcüklerin anlamları ve sözcükler arası bağlantıları yöneten kurallar sistemidir. Basitçe "ne demek istiyorsun?" sorusunun yanıtını anlam bilgisi bileşeni oluşturur. Anlam bilgisi bileşeni, sözcük ve sözcük öbeklerinin anlamı ve bağlamını düzenleyen kurallar sistemidir (Owens, 2012). Dilin iletişim amaçlı kullanılmasının sonucu olarak dil bir şey hakkında olmak zorundadır ve bu onun bağlamını, anlamını oluşturur. Anlam bilgisi, belirgin bir sözcüğü tanımlamak için bir araya gelen anlamsal parçaları temsil eder. Örneğin, "kız" ve "kadın” insan olma ve dişi olma özelliklerinin bağlamsal anlamını taşısa da, genç olmak sadece "kız" kavramını çağrıştırmaktadır. Anlam bilgisi bağlam içinde uygun tanımlama yapabilmek için kullanılan dil bileşenidir (Owens ve di ̌̆., 2003).

Çocuğun sözel olarak ürettiği ve anladığı sözcük sayısı, anlam bilgisi bileşenine ilişkin yeterliliğinin en basit ölçümlerinden biridir. Bununla birlikte anlam bilgisi, sadece çocuğun anladığı ve ürettiği farklı sözcük sayısı değil sözcüklerin bağlama ve kullanıma bağlı değişen anlamları üzerine de çalışır. Sözcükler, bağlamla ilişkili olarak karmaşık anlamlı, çok anlamlı, soyut anlamlı ya da mecazi anlamlı olabilir (Hedge ve Maul, 2006).

OSB olan çocuklarda anlam bilgisi gelişimi konusunda yapılan araştırmalar, OSB olan çocukların bu alanda sınırlılıklar yaşadıklarını göstermektedir (Kuder, 1997). OSB olan çocuklarda görülen anlam bilgisi bileşenine ilişkin sınırlılıkların arasında, sözcük bulmada sorunlar yaşamak (Owens, 1999) ve uydurulmuş, anlamlı olmayan sözcük kullanmak sıralanabilir (Wilkinson, 1998). OSB olan çocukların anlam bilgisi gelişimi ile ilgili yapılan araştırmaların birçok farklı bulgusu vardır. Bu çalışmalardan bazılarında OSB olan çocukların erken dönem sözcük dağarcığı kazanımlarının karşılaştırılan gruplarla benzer bir süreç izlediği (Charman, Drew Baird ve Baird, 2003; Luyster, Lopez ve Lord, 2007), bununla birlikte gelişim sürecinde gecikmeler olduğu bulunmuştur (Charman ve diğ., 2003). Luyster ve diğerleri (2007), ortalama 30 aylık OSB olan çocukların dil gelişimlerini, gelişim geriliği olan ve normal gelişim gösteren çocuklarla karşılaştıran bir çalışmada OSB olan çocukların sözel olmayan zeka yaşlarına göre eşleştirildikleri normal gelişen ve gelişim geriliği olan çocuklarla benzer alıcı ve ifade edici sözcük dağarcığı profili gösterdiklerini bulmuşlardır. Benzer bir çalışma yapan Charman ve diğerleri (2003), araştırmalarında OSB olan çocukların sözcük dağarcığı gelişimlerinde normal gelişen çocuklara oranla gecikmeler olduğunu bulmuşlardır. Normal gelişen çocuklarda dili anlamaya ilişkin erken belirtilerin ilk yılın sonuna doğru ortaya çıktı̆̆ı, OSB olan çocukların \% 50'sinde sözel olmayan zeka bölümüne ilişkin yaşları 2,6 olana kadar dili anlama belirtilerinin görülmediği bulunmuştur. Araştırmacılar sözcük anlamada sözcük üretmeye oranla daha fazla gecikme olduğunu bulmuşlar ve bunun atipik bir özellik olduğunu belirtmişlerdir. Eigsti ve diğerleri (2007), küçük yaşlardaki (3-6 yaş) OSB olan çocukların alıcı sözcük dağarcıklarının sözdizimine göre görece güçlü bir alan olduğunu öne sürmüşlerdir. OSB olan çocukların alıcı dil performanslarına, sözel olmayan zeka yaşlarına ve cinsiyetlerine göre eşleştirildiklerinde, serbest oyun ortamında normal gelişen çocuklarla benzer oranda farklı sözcük ürettiklerini bulmuşlardır. Gecikmiş dil görülen çocuklarla karşılaştırıldığında ise, OSB olan çocukların sık kullandıkları sözcük kategorilerinin karşılaştırma grubu ile benzer olduğu bulunmuştur (Weismer ve diğg., 2011).

Araştırmalar, OSB olan çocukların normal gelişen ve gelişim geriliği olan çocuklarla sözcük kazanımlarını incelemekle kalmamış, üretilen sözcük türlerine de bakılmıştır. OSB olan çocukların sözcük dağarcıklarında belirli tür sözcüklerin kullanımında sınırlılıklar bulunmaktadır (Tager-Flusberg ve diğ., 2005). OSB olan çocukların normal gelişen çocuklarla karşılaştırıldıklarında, özellikle zihinsel durum ifade eden fiillerde sınırlılıklar yaşadıkları (bilmek, düşünmek, hatırlamak vb.), Down sendromlu çocuklarla karşılaştırıldıklarında ise daha az zihinsel durum ve duygu sözcüğü kullandıkları bulunmuştur (Tager-Flusberg, 1992). Sözel olmayan zeka yaşlarına göre eşleştirilmiş OSB olan çocuklar, zihinsel engelli ve normal gelişen çocuklarla iki farklı hafıza deneyi yapan Tager-Flusberg (1991), ilk denemede anlamsal olarak ilişkili sözcük ve ilişkisiz sözcük listesini hatırlama testi uygulamıştır. Bu işlem sonucunda OSB olan çocukların ilişkili sözcük 
listesini hatırlamada, kontrol grubundan daha düşük bir performans gösterdiği bulunmuştur. İkinci işlemde ise kafiye (ses uyumu) ve bağlamsal ipuçlarını kullanarak daha önce hatırlayamadığı sözcükleri hatırlama testi uygulanmıştır. Bu işlemde OSB olan çocuklarla kontrol grubu arasında anlamlı bir farklılık bulunmamıştır. Bu araştırmanın sonunda, OSB olan çocukların belleğe depolanmış bilgileri hatırlamayı (çağrıştırmada) kolaylaştırmak için dilbilimsel bilgilerini kullanamadıkları iddia edilmiş ve OSB olan çocuklarda bu süreçle ilgili bilişsel bir sınırlılık olduğu öne sürülmüştür. Araştırmacılar, OSB olan çocukların belleğe depolama stratejilerinde sorunlar olduğunu ve bunun zihin kuramının gelişmesindeki sıkıntılarla da ilişkili olduğunu ileri sürmüşlerdir. Bu hipotezleri inceleyen Tager-Flusberg (1992), kronolojik yaşlarına ve dil performanslarına (OSU) göre eşleştirilen 3-7 yaş arası OSB olan çocukların ve Down sendromlu çocukların boylamsal olarak dil gelişimlerini inceleyen bir çalışma yapmıştır. Çalışmasında dil örneği toplayarak özellikle bilişsel durum ifadelerini içeren zihinsel terimlerin kullanımını incelemiştir. Araştırmanın sonucunda, OSB olan çocukların zihinsel terimleri kullanmakta özellikle bilmek, düşünmek, hatırlamak ve -mış gibi yapmak gibi bilişsel süreç ifadelerini kullanmakta sınırlılıkları olduğu bulunmuştur. Sözcük dağarcığı OSB olan çocukların dil gelişiminde görece güçlü oldukları bir alan olması ile birlikte, zihinsel durum belirten sözcüklerin ediniminin özgün olarak sınırlılıklar yaşadıkları bir alan olabileceği düşünülmektedir (Tager-Flusberg ve diğ., 2005; Ziatas, Durkin ve Pratt 1998).

OSB olan çocuklar da normal gelişim gösteren çocuklar gibi aynı kategoriye ait sözcükleri anlama ve kullanma yeterliliğine sahiptir. Bununla birlikte sözcükleri kullanım biçimlerinde normal gelişen çocuklara göre sıra dışı özellikler görülebilir (Tager-Flusberg, ve diğ., 2005). OSB olan çocuklarda sözcük kazanımı başladıktan sonra, uydurulmuş, bağlama uygun olmayan sözcük ve sözcük grupları kullanma (nonsense words) görülebilmektedir. Bunun yanı sıra bağlama uygun olmayan sözcük ve sözcük gruplarının tekrarı (ekolali) gibi sıra dışı kullanım örüntüleri görülebilmektedir. Bu sıra dışı kullanımların sıklığının fazla olması ve sürekliliği, OSB olan çocukları diğer gruplardan ayırmaktadır. Sıra dışı kullanımların sembolik ya da kavramsal gelişim ile ilgili olmayabileceği düşünülmektedir. OSB olan çocuklarda sözcükler ile kavramları ilişkilendirme, kavramları hafizaya depolamada sıra dişı problemler görülmemektedir. Bunun yerine eksiklikler, kavramsal ve sembolik bilgiyi işlevsel görevlerde kullanma sürecinde yaşanmaktadır (Wilkinson, 1998).

Sonuç olarak OSB olan çocuklarda sözcük dağarcığı gelişiminde normal gelişim gösteren çocuklarla benzer bir gelişim süreci görülmekle birlikte, sözcük kazanım sürecinde gecikmelerin söz konusu olduğu söylenebilir. OSB olan çocuklarda anlam bilgisi bileşeni kapsamında sözcük dağarcığı gelişiminde gecikmenin yanı sıra, anlamsız sözcük kullanma ve sözcük uydurma gibi sıra dışı gelişimsel özellikler de görülebilmektedir (Wilkinson, 1998). Alanayazında yapılan araştırmalar, OSB olan çocukların anlam bilgisi bileşenine ilişkin yaşadıkları bozukluklardan birinin zihinsel terim ifadelerini kullanmakta yaşadıkları sınırlılıklar olduğunu göstermektedir. OSB olan çocukların özellikle bilişsel durum ifade eden zihinsel terimleri kullanmakta sınırlılıklar yaşadıkları araştırma bulguları ile desteklenmektedir (Tager-Flusberg ve diğ., 2005). Wilkinson (1998), OSB olan çocukların anlam bilgisine ilişkin gelişimlerini ele alırken, OSB olan çocukların sözcükleri kavramlarla ilişkilendirmede ya da kavramları belleğe depolamada ve organize etmede bir sınırlılık yaşamadıklarını öne sürmüştür. Wilkinson OSB olan çocukların kavramsal ya da sembolik bilginin (sözcüklerin) işlevsel görevlere yani işlevsel kullanıma aktarımında sorun yaşadıklarını öne sürmüştür. Bir sonraki başlık altında OSB olan çocuklarda kullanım bilgisi bileşeni ele alınmakta, dilin işlevsel kullanımına ilişsin gelişimsel özellikler verilmektedir.

\section{OSB Olan Çocuklarda Kullanım Bilgisi Gelişimi}

Kullanım bilgisi dilin kullanımının sosyal bileşenini oluşturmaktadır (Owens, 2012; Wilkinson, 1998). Kullanım bilgisi, bir şeyin yapılmasını sağlamak ve bir şey elde etmek için sözcükler ya da jestler kullanılarak ortaya konulan davranışların iletişimsel işlevi ya da amacı olarak tanımlanabilir. İletişimsel amacı ya da işlevi olmaksızın dilin diğer bileşenleri anlamsızdır (Westby, 2014). Kullanım bilgisi, sosyal bağlamlar içinde dilin kullanımı üzerine odaklanır. Dolayısı ile kullanım bilgisi, dilin yapısal özelliklerine değil işlevsel özellikleri üzerine odaklanır. Kullanım bilgisi bileşenine ilişkin birçok özellik, konuşmacıların sosyal bir sohbete 
katılmaları ile ortaya çıkar. Kullanım bilgisine ilişkin özellikler, sohbet başlatma, sohbette sıra alma, sohbet sırasında konuyu sürdürme, konu değiştirme, konuşmayı düzenleme, iletişim kopukluklarının düzeltilmesi isteğinde bulunma, iletişimsel kopuklukların düzeltilmesi isteklerini yanıtlama, bağlama ve duruma uygun sözce üretme ve deneyimler ile olayları öyküleme olarak sıralanabilir (Hedge ve Maul, 2006).

OSB olan çocukların dil gelişimi ile ilgili temel özellik, tüm OSB olan çocuklarda dilin kullanım bilgisi bileşenine ilişkin bozukluklar görülmesidir (Lord ve Paul, 1997; Wilkinson, 1998). OSB olan çocuklarda kullanım bilgisi bileşeninde görülen bozukluklar, tüm sosyal iletişim davranışlarında görülen sınırlılıklarla ilişkilidir (Wilkinson, 1998; Kuder, 1997) ve bu bozukluklar tanı ölçütlerinden de birisidir (Hedge ve Maul, 2006). OSB olan çocuklarda kullanım bilgisine ilişkin olarak sohbette sıra alma, konu seçme, sohbete sohbet bağlamı ile ilişkili katkıda bulunma (Wilkinson, 1998), sohbet konusunu sürdürme gibi karşılıklı sohbet ve sohbet kurallarına uyma sürecinde güçlükler görülmektedir (Tager-Flusberg, 1997; Tager-Flusberg ve Anderson, 1991). Sohbet konusu başlatmada güçlükler, sohbet sırasında gereksinim duyulduğunda açıklama yapmada sınırlılıklar ve sohbet bağlamına uygun olmayan sözceler kullanma gibi davranışlar, OSB olan çocuklarda görülen kullanım bilgisine ilişkin diğer bozukluklardır (Hedge ve Maul, 2006). Dilin kullanım bilgisi bileşenine ilişkin bozukluklar, sınırlı konuşma becerilerine sahip olan çocuklardan iyi konuşma becerilerine sahip olan çocuklara kadar tüm OSB olan çocuklarda görülür (Wilkinson, 1998). Bunların yanı sıra anlam bilgisi bileşeni başlığı altında söz edilen sözcük uydurma, gecikmiş ekolali gibi sıra dışı kullanımlar, dilin kullanım bilgisi bileşenine ilişkin sorunlar olarak ele alınabilir (Tager-Flusberg ve diğ., 2005).

Dil performanslarına ve kronolojik yaşlarına göre eşleştirilmiş 3-6 yaş arası OSB olan ve Down sendromlu çocukların dil gelişimlerini inceleyen Tager-Flusberg ve Anderson (1991), OSB olan çocukların dilin erken dönemlerinde anneleri ile etkileşimlerinin, Down sendromlu çocuklara ve normal gelişen çocuklara benzer bir örüntüde geliştiğini, bununla birlikte dil gelişiminin ilerlemesi ile OSB olan çocuklarda dilin kullanım bilgisi bileşenine ilişkin farklılıkların başladığını bulmuşlardır. Araştırma sonunda, OSU'larının 2.0'ın altında olduğu dönemlerde OSB olan çocukların, sohbette sıra alma becerilerinde Down sendromlu çocuklarla benzer özellikler gösterdiği bulunmuştur. Araştırmacılar bu bulguyu, sözel iletişimi yeni kazanma aşamasında olan OSB'li çocukların, anneleri ile tanıdık bağlamlarda iken sohbet becerilerinde özgün bir bozukluk olmadığı yönünde tartışmışlardır. Bununla birlikte dil gelişiminin ilerleyen dönemlerinde, OSU 2.00'nin üzerine çıktığında, dolayısı ile çocuklar sözcükleri birleştirme ve cümle kurma aşamasına geçtiklerinde, kullanım bilgisine ilişkin ölçümlerde gruplar arası farklılıklar olduğu bulunmuştur. Araştırmacılar, OSB olan çocuklarda dilin biçim bileşenlerinin gelişmesi ile paralel olarak sohbet becerilerinde normal gelişen ve Down sendromlu çocuklardan farklı olarak gelişim gözlenmediğini öne sürmüşlerdir. Çocukların sohbeti sürdürme stratejilerindeki bu farklılıklar özellikle dikkat çekicidir. OSB olan çocuklar, sohbeti sürdürmede sohbeti genişletme için yeni bilgi ekleme ve yeni sohbet konusu başlatma davranışlarında sınırlılıklar göstermişlerdir. Dil gelişim aşamaları daha karmaşık sohbet sürdürme yollarını kullanmalarını sağlayacak düzeyde olmasına rağmen, sohbeti sürdürmek için sohbet rutinlerini tekrarlamak (merhaba vb. rutinler), sözceyi tekrarlamak, soruları basit yanıtlamak gibi daha basit stratejileri kullanmışlardır. Araştırmacılar, sohbet becerilerinde görülen bu bozukluklar ile zihin kuramı gelişimi arasında doğrudan bir ilişki bulunduğunu öne sürmüşlerdir.

Sohbet becerileri ve ilişkili olarak kullanım bilgisi, dilin yapısal biçimini anlamayı, bununla birlikte sosyal etkileşim içinde bu yapıları kullanma biçimini içerir (Eigsti, Marchena, Schuh ve Kelley, 2011). OSB olan çocuklar, dili sosyal etkileşim başlatma, bilgi isteme, dinleyiciyi onaylama ve yorumlama için sınırlı olarak kullanmaktadırlar (Tager-Flusberg ve diğ., 2005). Ziatas, Durkin ve Pratt (2003), çalışmalarında cinsiyet ve sözel zeka yaşlarına göre eşleştirdikleri ortalama OSB olan çocukların, özgül dil bozukluğu olan ve normal gelişen çocuklarla sözel dil kullanımlarının içeriklerini karşılaştırmışlardır. Araştırmanın sonucunda OSB olan çocukların daha fazla etiketleme cümlesi kurduklarını (bu bir araba gibi) ve daha seyrek açıklama ifadesi kullandıklarını bulmuşlardır. Bağlam içinde oluşan durumlar için kontrol gruplarına göre daha az sıklıkta olay açıklama cümlesi kuran OSB olan çocuklar (örn., şimdi iniyor), zihinsel durum ifadelerini kullanmada da (nasıl yapılacağını biliyorum gibi) daha düşük performans göstermişlerdir. Yapılan analizler sonucunda araştırmacılar, 
OSB olan çocukların kendilerinin ve başkalarının düşünce ve inançlarına yönelik ifadeleri daha az sıklıkta kullandıklarını ve cümlelerinin çoğunlukla istek ifadelerinden oluştuğunu bulmuşlardır. OSB olan çocuklarda kullanım bilgisine ilişkin görülen diğer özellikler ise, normal gelişen ve gelişim geriliği olan çocuklarla karşılaştırıldıklarında sohbet sırasında konuya katkıda bulunmayan sözceleri daha fazla kullanma, daha fazla oranda kendi sözcelerini ya da karşılıklı konuşulan bireyin sözcelerini tekrar etme, kendilerine yönelik doğrudan sorulan soruları yanıtlayamama ya da görmezden gelme olarak siralanabilir.

OSB olan çocuklarda sohbet sırasında kendisine sorulan sorulara cevap olmayan ve ilişkisiz tepkilerde bulunma ile ekolali kullanımı sıklıkla görülmektedir (Eales, 1993; Roberts ve dĭg., 2004). OSB olan çocuklarda ekolali kullanımı, işitilen sözcenin hemen tekrarlanması ile anlık ya da gecikmiş olarak ortaya çıkabilir (TagerFlusberg ve diğ., 2005). OSB olan çocuklarda görülen anlık veya gecikmiş ekolali, erken dönemlerde normal gelişen çocukların dil gelişim sürecinde de görülen bir özelliktir. Bu özellik normal gelişen çocukların aksine OSB olan çocuklarda daha uzun bir süre devam etmektedir (Eigsti ve diğ., 2007). OSB olan çocuklarda ekolali kullanımın anlamsız ya da uygun olmayan davranış olmaktan ziyade iletişimsel işlevi olduğunu öne süren Prizant ve Duchan (1981), OSB olan çocukların anlık ekolali davranışlarını etkileşim bağlamı içinde incelemişlerdir. Araştırmanın sonucunda OSB olan çocukların anlık ekolali davranışlarının yedi farklı işlev için kullanıldığını bulmuşlardır. Anlık ekolalinin OSB olan çocuklar tarafından, iletişimsel sıra almak, hak iddia etmek, kendini düzenlemek, istekte bulunmak, olumlu yanıt vermek gibi iletişimsel amaçlarla kullanıldığ bulunmuştur. Çocukların ekolaliyi korku ve acı gibi yüksek uyarı ile karşılaştıklarında bir odak olmadan kullandıkları, sohbette sıra almak için kullandıkları, nesne eylem ya da durumu etiketleme amaçlı kullandıkları, kendi eylemlerini düzenlemek için, daha önce ifade edilen sözceyi onaylamak için, istek ifade etmek için kullandıkları gözlenmiştir. Ekolali, OSB olan çocuklarda konuşmanın ilk ortaya çıtığı dönemde, konuşmanın ilk biçimi olarak ortaya çıkmaktadır. Anlık ekolalinin bir dil stratejisi işlevinde kullanılması, iletişim gelişimini desteklediğinin göstergesidir. Anlık ekolali kullanımı ile OSB olan çocuklar, dilin daha karmaşık biçimlerini kazanmak için olanak oluşturabilirler (McEvoy, Loveland ve Landry, 1988).

OSB olan çocuklarda gecikmiş ekolali, düşen bir çocuğun "tamam geçti” sözcesini kullanmasında olduğu gibi, sözce ile ilişkili durumların yeniden oluşturulmasına dair istek ifade etme amaçlı kullanılabilmektedir. Ekolali kullanımının OSB olan çocuklarda iletişim amaçlı olabileceği gibi (Eigsti ve diğ., 2007; Kuder, 1997), bilgiyi hafızada tutma yolu ya da tanıdık sözel rutin olarak da kullanıldığı düşünülmektedir (Eigsti ve diğ., 2007). Dili anlama ve ekolali arasındaki ilişkiyi inceleyen Roberts (1989), OSB olan çocuklarda dili anlama yeterliliği geliştikçe ekolali kullanımının azaldığını bulmuştur. OSB olan çocuklarda ekolali ve dil gelişimi üzerine yapılan araştırmalar da, OSB olan çocuklarda ekolali kullanımının, çocukların dil yeterlilikleri geliştiğinde azaldığını ortaya koymaktadır (Howlin, 1982; McEvoy ve diğ., 1988). Tager-Flusberg ve Calkins (1990), yaptıkları çalışmada dil gelişimin erken aşamalarında olan OSB'li çocukların daha fazla ekolali ve kalıp ifadeleri kullandıklarını ve bu kullanımların dildeki gelişim ile hızla azaldığını bulmuşlardır. Aynı çalışmada OSB olan çocukların ürettikleri spontan sözcelerin, ekolali içeren sözcelerden daha karmaşık dilbilgisel yapılar içermesi nedeniyle, ekolalinin karmaşık dilbilgisel yapıların kazanımında ilerletici bir rolü olmadığını öne sürmüşlerdir. Tüm bu bulgular göz önüne alındığında OSB olan çocuklarda ekolali kullanımının iletişim amaçlı olduğu ve dil kazanımında bir geçiş süreci olduğu söylenebilir.

OSB olan çocuklarda dilin kullanım bilgisi bileşenine ilişkin önemli bir özellik de kullanım bilgisinin bazı yönlerinin çocuğun gelişimi ile değişime uğraması (örn., sosyal davranışların gelişimi ile OSB olan çocuğun iletişim becerilerinin de gelişmesi), bazı yönlerinin ise sabit kalmasıdır (örn., yorumlama ifadelerinde sınırlılıklar, sohbet konusuna yeni bilgi eklemede sınırlılıklar). Farklı yaşlardaki çocuklarda bağlamsal iletişim isteklerinin de farklı olması ve farklı bağlamların farklı yeterlilikleri gerektirmesi ile yine kullanım bilgisi bileşeninde değişimler meydana gelir. Sonuç olarak dilin kullanımına ilişkin değerlendirme ve yorum yapılırken bireyden beklenilenler, bireye verilen firsatlar, bireyin genellikle neler yaptığı gibi bileşenler işin içine alınmalıdır (Tager-Flusberg ve diğ., 2005). OSB olan çocuklarda görülen kullanım bilgisine ilişkin bozukluklar, 
etkili iletişim kurmalarını, olumlu sosyal etkileşim yaşantısı sağlamalarını ve sosyal ilişki geliştirmelerini zorlaştırmanın yanı sıra sosyal ilişkilerde yanlış anlaşılmalara da yol açabilmektedir (Suh ve diğ., 2014).

Sonuç olarak OSB olan çocuklarda dilin kullanım bilgisine ilişkin bozukluklar görülmektedir (Lord ve Paul, 1997) ve bu bozukluklar OSB'nin tanı ölçütlerinden biri olarak ele alınmaktadır (Hedge ve Maul, 2006). OSB olan çocuklarda dilin kullanım bilgisine ilişkin bozukluklar, söz öncesi dönemde ortak dikkat ve jestler gibi erken dönem sözel olmayan sosyal iletişim becerilerinde bozukluklarla başlamakta (Wilkinson, 1998) sözel dilin kazanımı ile ise yeni sohbet konusu başlatma, sohbette konuya ilişkin sözce üretme, iletişim kopukluklarını düzeltme gibi dilin işlevsel kullanımna ilişkin bozukluklarla kendini göstermektedir (Tager-Flusberg ve Anderson, 1991).

\section{Sonuç ve Öneriler}

Dil ve iletişim alanında yaşanan güçlükler OSB'nin tanı ölçütlerinden ve OSB olan çocuklarda sendromun şiddetini belirleyen değişkenlerden birisidir (APA, 2013). Bununla birlikte OSB olan çocuklarda dil ve iletişim becerilerinde görülen bozukluklar gelişimin erken dönemlerinden itibaren ortaya çıkmakta ve birçok gelişimsel alanı olumsuz yönde etkilemektedir (Landa, 2007). Bu nedenle OSB olan çocukların dil ve iletişim becerilerine ilişkin özellikler, teorik ve uygulamalı çalışmalarda önde gelen bir alandır. Özellikle OSB olan bazı çocuklarda sözel dil gelişirken bazı çocuklarda sözel dil kazanımının olmamasının, dilin bileşenlerinde ise farklı derecelerde bozukluk ya da gecikmelerin olmasının nedenleri alanyazında tartışılan konulardır (Tager-Flusberg ve diğ., 2005). Bu derleme çalışmasında OSB olan çocuklarda söz öncesi dönemde sözel olmayan sosyal iletişim becerilerinin gelişim özelliklerine, sözel dil döneminde ise dilin biçimbirim bilgisi, söz dizimi, anlam bilgisi ve kullanım bilgisine ilişskin gelişim özelliklerine yönelik birçok araştırma bulgusu verilmiştir.

Alanyanzın araştırmaları göz önüne alınarak OSB olan çocuklarda görülen iletişim bozukluklarının söz öncesi dönemden itibaren başladığı, OSB olan çocukların söz öncesi sözel olmayan sosyal iletişim becerilerinden taklit, ortak dikkat, jest ve oyun becerilerinde sınırlılıklar yaşadıkları söylenebilir. Söz öncesi dönemde sözel olmayan sosyal iletişim becerilerinde yaşanan bu güçlüklerin, çocuklarda dilin kazanımında yaşanan güçlükler ile ilişkili olduğu düşünülmektedir. Söz öncesi dönemde kazanılan sözel olmayan sosyal iletişim becerilerinin sözel dil gelişiminin öncülü olarak kabul edilmesi (Bruner, 1975; Carpenter ve diğ., 1998; Tomasello, 2003) ve OSB olan çocuklarda söz öncesi iletişim becerilerinin dil gelişimi ile ilişkili olduğunu gösteren bir çok araştırma bulgusu da (örn., Bono ve diğ., 2004; Ökcün-Akçamuş, 2015; Toth ve diğ., 2006) bu görüşü desteklemektedir. Tüm bunlar göz önüne alındığında, kendini sözel olarak ifade etme becerilerine sahip olmayan, farklı bir ifade ile söz öncesi dönemde olan OSB'li çocukların dil ve iletişim becerilerinin değerlendirilmesi sürecinde, çocukların sözel olmayann amaçlı iletişim davranışlarının değerlendirilmesinin önemli olduğu düşünülmektedir. Amaçlı iletişim, söz öncesi dönemde olan bebeklerin sesler ve jestler eşliğinde yetişkine yöneltilen koordineli dikkat ile iletişim kurmaları olarak tanımlanabilir (Adamson ve Bakeman, 1991). Tomasello'ya göre (2003), ilk sözcüklerin ortaya çıkmasında anahtar nokta dilden hemen önce ortaya çıkan amaçlı iletişim davranışlarıdır ve çocuklarda ilk sözcüklerin edinimi ortak dikkat, niyeti anlama, taklit gibi temel beceriler ile gerçekleşmektedir. Bununla birlikte bu çalışmada incelenen araştırmalarda da görüldüğü üzere, OSB olan çocuklarda sözel olmayan sosyal iletişim becerilerine ilişkin sendroma özgü bozukluklar ve gecikmeler görülmektedir. Dolayısı ile sözel dili kazanmamış olan OSB'li çocukların sözel olmayan amaçlı iletişim davranışlarının değerlendirilmesinin, hem çocukların iletişim becerilerine ilişkin derinlemesine bilgi vereceği hem de ugun müdahale planı geliştirmek için yol gösterici olacağı düşünülmektedir. Söz öncesi sosyal iletişim becerileri üzerine yapılan müdahalenin hem söz öncesi sosyal iletişim becerilerini hem de dil becerilerini etkilemesi nedeniyle (Yoder ve Warren, 1993), söz öncesi dönemde olan OSB'li çocuklarda sözel olmayan sosyal iletişim becerilerinde sinırlılıklar olması durumunda, sözel dile yönelik müdahale geliştirmeden önce bu becerilerin desteklenmesinin önemli olduğu düşünülmektedir.

OSB olan çocukların sözel dili kazanmaları durumunda dil gelişimlerinde bireysel farklılıklar görülmektedir. Dolayısıyla OSB olan çocukların dil gelişiminde heterojen bir yapının varlığından söz edilebilir 
(Tager-Flusberg ve diğ., 2005). OSB olan çocuklarda özellikle dilin kullanım bilgisine ilişkin bozukluklar görülmesi (Hedge ve Maul, 2006), çocukların bir kısmında biçimbirim bilgisi ve sözdizimi gelişiminde gecikmeler (Tager-Flusberg ve diğ., 1990) ve ek atma gibi bozukluklar görülmesi (Bartolucci ve diğg., 1980), yine çocukların bir ksımında sözcük kazanımında gecikmeler (Charman ve diğ., 2003) ve zihinsel durum ifade eden bazı sözcüklerin kullanımında güçlükler görülmesi (Tager-Flusberg, 1992), OSB olan çocukların dilin bileşenlerine göre gösterdikleri gelişimsel özellikler olarak sıralanabilir. Araştırmalarda da görüldüğü üzere OSB olan çocuklar dilin farklı bileşenlerinde farklı gelişimsel özellikler göstermektedir. Wilkinson (1998), OSB olan çocuklarda dil gelişiminde görülen en belirgin özelliğin "dilin biçimsel özelliklerinin işlevsel iletişim amacı ile kullanılamaması” olduğunu öne sürmüştür. Bu çalışmada incelenen araştırmalar göz önüne alındığında da OSB olan çocuklarda dilin biçimbirim bilgisi/sözdiziminde bir gecikmeden söz edilebilirken, dilin işlevsel kullanımını içeren kullanım bilgisi gelişiminde belirgin bir bozukluktan söz etmek mümkündür. Bu bulguların uygulamaya yansıması önemlidir. OSB olan çocukların dil gelişimini desteklemeye yönelik bir planlama yapılırken kullanım bilgisi bileşenine yönelik değerlendirme yapılmasının ve çocuğa uygun amaçlar alınmasının önemli olduğu düşünülmektedir. 


\section{Kaynaklar}

Acredolo, L. P., \& Goodwyn, S. W. (1988). Symbolic gesturing in normal infants. Child Development, 59(2), 450-466.

Adamson, L. B., \& Bakeman, R. (1991). The development of shared attention during infancy. Annals of Child Development, 8,1-41.

American Psychiatric Association. (2013). Diagnostic and statistical manual of mental disorders (5th ed.). Arlington, VA: American Psychiatric Publishing.

Baldwin, D. A. (1995). Understanding the link between joint attention and language. In C. Moore, \& P. J. Dunham (Eds.), Joint Attention: Its origins and the role in development (pp. 131-158). New York, NY: Psychology Press.

Baranek, G. T. (1999). Autism during infancy: A retrospective video analysis of sensory-motor and social behaviors at 9-12 months of age. Journal of Autism and Developmental Disorders, 29(3), 213-224.

Baranek, G. T., Barnett, C. R., Adams, E. M., Walcott, N. A., Watson, L. R., \& Crais E. R. (2005). Object play in infants with autism: Methodological issues in retrospective video analysis. American Journal of Occupational Therapy, 59(1), 20-30.

Baranek, G. T., Reinhartsen, D., \& Wannamaker, S. (2001). Play: Engaging children with autism. In R. Heubner (Eds.), Sensorimotor interventions in autism (pp. 311-351). Philadelphia: Davis.

Bartolucci, G., \& Albers, R. J. (1974). Deictic categories in the language of autistic children. Journal of Autism and Childhood Schizophrenia, 4(2), 131-141.

Bartolucci, G., Pierce, S. J., \& Streiner, D. (1980). Cross-sectional studies of grammatical morphemes in autistic and mentally retarded children. Journal of Autism and Developmental Disorders, 10(1), 39-50.

Bates, E., Camaioni, L., \& Volterra, V. (1975). The acquisition of performatives prior to speech. Merrill-Palmer Quarterly of Behavior and Development, 21(3), 205-226.

Bono, M. A., Daley, T., \& Sigman, M. (2004). Relations among joint attention, amount of intervention and language gain in autism. Journal of Autism and Developmental Disorders, 34(5), 495-505.

Brown, J., \& Whiten, A. (2000). Imitation, theory of mind and related activities in autism: An observational study of spontaneous behavior in everyday contexts. Autism, 4(2), 185-204.

Bruner, J. (1975). From communication to language - A psychological perspective. Cognition, 3(3), 255-287.

Camaioni, L., Perucchini, P., Muratori, F., Parrini, B., \& Cesari, A. (2003). The communicative use of pointing in autism: Developmental profile and factors related to change. European Psychiatry, 18(1), 6-12.

Carpenter, M. (2006). Instrumental, social, and shared goals and intentions in imitation. In S. J. Rogers \& J. H. G. Williams (Eds.), Imitation and the social mind: Autism and the typical development (pp. 48-70). New York, NY: The Guilford Press.

Carpenter, M., Nagell, K., \& Tomasello, M. (1998). Social cognition, joint attention, and communicative competence from 9 to 15 months of age. Monographs of the Society for Research in Child Development, 63 (4, Serial No. 255).

Charman, T., \& Baron-Cohen, S. (1997). Brief report: Prompted pretend play in autism. Journal of Autism and Developmental Disorders, 27(3), 325-332. 
Charman, T., Drew, A., Baird, C., \& Baird, G. (2003). Measuring early language development in preschool children with autism spectrum disorder using MacArthur Communicative Development Inventory (Infant Form). Journal of Child Language, 30(1), 213-236.

Charman,T., Swettenham, J., Baron-Cohen, S., Cox, S., Baird, G., \& Drew, A. (1997). Infants with autism: An investigation of empathy, pretend play, joint attention, and imitation. Developmental Psychology, 33(5), 781-789.

Chawarska, K., \& Volkmar, F. R. (2005). Autism in infancy and early childhood. In F.R. Volkmar, R. Paul., A. Klin \& D. Cohen (Eds.), Handbook of autism and pervasive developmental disorders (3th ed., pp. 223246). Hoboken, New Jersey: John Wiley \& Sons, Inc.

Colgan, S. E., Lanter, E., McComish, C., Watson, L., Caris, E., \& Baranek, G. T. (2006). Analysis of social interaction gestures in infants with autism. Child Neuropsychology, 12(4-5), 307-319.

Crais, E. (2007). Gesture development from an interactionist perspective. In R. Paul (Eds.), Language disorders from a developmental perspective: Essays in honor of Robin S. Chapman (pp. 141-162). Mahwah, NJ: Lawrence Erlbaum Associates.

Crais, E., Douglas, D. D., \& Campell, C. C. (2004). The intersection of the development of gestures and intentionality. Journal of Speech, Language, and Hearing Research, 47(3), 678-694.

Dawson, G., \& Galpert, L. (1986). A developmental model for facilitating the social behavior of autistic children. In E. Schopler \& G. B. Mesibov (Eds.), Social behavior in autism (pp. 237-256). New York, NY: Plenum Press.

Dawson, G., Meltzoff, A. N., Osterling, J., Rinaldi, J., \& Brown, E. (1998). Children with autism fail to orient to naturally occurring social stimuli. Journal of Autism and Developmental Disorders, 28(6), 479-485.

Dawson, G., Toth, K., Abbott, R., Osterling, J., Munson, J., Estes, A., et al. (2004). Early social attention impairments in autism: Social orienting, joint attention, and attention to distress. Developmental Psychology, 40(2), 271-283.

Eales, M. J. (1993). Pragmatic impairments in adults with childhood diagnoses of autism or developmental receptive language disorder. Journal of Autism and Developmental Disorders, 23(4), 593-617.

Eigsti, I. M., Bennetto, L., \& Dadlani, M. B. (2007). Beyond pragmatics: Morphosyntactic development in autism. Journal of Autism and Developmental Disorders, 37(6), 1007-1023.

Eigsti, I. M., Marchena, A. B., Schuh, J. M., \& Kelley, E. (2011). Language acquisition in autism spectrum disorders: A developmental review. Research in Autism Spectrum Disorders, 5(2), 681-691.

Garvey, C. (1990). Play: The developing child (Rev.ed.). Cambridge, MA: Harvard University Press.

Ginsburg, K. R. (2007). The importance of play in promoting healthy child development and maintaining strong parent-child bonds. Pediatrics, 119(1), 182-191.

Gullberg, M., de Bot, K., \& Volterra, V. (2010). Gestures and some key issues in the study of language development. In M. Gullberg \& K. de Bot (Eds.), Gestures in language development (pp. 3-33). Philadelphia: John Benjamins Publishing.

Hedge, M. N., \& Maul, C. A. (2006). Language disorders in children: An evidence-based approach to assessment and treatment. Boston: Pearson Education.

Hobson, J. A., \& Hobson, R. P. (2007). Identification: The missing link between joint attention and imitation. Development and Psychopathology, 19(2), 411-431. 
Hobson, R. P., Lee, A., \& Hobson, J. A. (2009). Qualities of symbolic play among children with autism: A social-developmental perspective. Journal of Autism and Developmental Disorders, 39(1), 12-22.

Howlin, P. (1982). Echolalic and spontaneous phrase speech in autistic children. Child Psychology \& Psychiatry \& Allied Disciplines, 23(3), 281-293.

Ingersoll, B. (2008a). The social role if imitation in autism: Implications for the treatment of imitation deficits. Infants \& Young Children, 21(2), 107-119.

Ingersoll, B. (2008b). The effect of context on imitation skills in children with autism. Research in Autism Spectrum Disorders, 2(2), 332-340.

Iverson, J. M., \& Goldin-Meadow, S. (2005). Gesture paves the way for language development. Psychological Science, 16(5), 367-371.

Iverson, J. M., \& Thal, D. J. (1998). Communicative transitions: There's more to the hand than meets the eye. In A. M. Wetherby, S. F. Warren \& J. Reichle (Eds.), Transitions in prelinguistic communication (pp. 5986). Baltimore, Maryland: Paul H. Brookes Publishing.

Jones, E. J. H., \& Herbert, J. S. (2006). Exploring memory in infancy: Deferred imitation and the development of declarative memory. Infant and Child Development, 15(2), 195-205.

Kjelgaard, M. M., \& Tager-Flusberg, H. (2001). An investigation of language impairment in autism: Implications for genetic subgroups. Language and Cognitive Processes, 16(2-3), 287-308.

Kuder, S. J. (1997). Teaching students with language and communication disabilities. Needham Heights, MA: Allyn \& Bacon.

Landa, R. (2007). Early communication development and intervention for children with autism. Mental Retardation and Developmental Disabilities, 13(1), 16-25.

Leekam, S., Baron-Cohen, S., Perrett , D., Milders, M., \& Brown, S. (1997). Eye-direction detection: A dissociation between geometric and joint skills in autism. British Journal of Developmental Psychology, 15(1), 77-95.

Leslie, A. M. (1987). Pretense and representation: The origins of "theory of mind". Psychology Review, 94(4), $412-426$.

Lewy, A. L., \& Dawson, G. (1992). Social stimulation and joint attention in young autistic children. Journal of Abnormal Child Psychology, 20(6), 555-566.

Libby, S., Powell, S., Messer, D., \& Jordan R. (1998). Spontaneous play in children with autism: A reappraisal. Journal of Autism and Developmental Disorders, 28(6), 487-497.

Lifter, K., \& Bloom, L. (1998). Intentionality and the role of play in the transition to language. In A. M. Wetherby, S. F. Warren \& J. Reichle (Eds.), Transitions in prelinguistic communication (pp. 161-195). Baltimore, Maryland: Paul H. Brookes Publishing.

Lord, C., \& Paul, R. (1997). Language and communication in autism. In D. J. Cohen \& F. R. Volkmar (Eds.), Handbook of autism and pervasive developmental disorders (pp. 195-225). New York: John Wiley \&Sons.

Lord, C., Risi, S., Lambrecht, L., Cook, E. H., Leventhal, B. L., DiLavore, et al. (2000). The Autism Diagnostic Observation Schedule-Generic: A standard measure of social and communication deficits associated with the spectrum of autism. Journal of Autism and Developmental Disorders, 30(3), 205-223. 
Luyster, R., Lopez, K., \& Lord, C. (2007). Characterizing communicative development in children referred for autism spectrum disorders using the MacArthur-Bates Communicative Development Inventory (CDI). Journal of Child Language, 34(3), 623-654.

McDuffie, A., Turner, L., Stone, W., Yoder, P., Wolery, M., \& Ulman, T. (2007). Developmental correlates of different types of motor imitation in young children with autism spectrum disorders. Journal of Autism and Developmental Disorders, 37(3), 401-412.

McEvoy, R. E., Loveland, K. A., \& Landry, S. H. (1988). The functions of immediate echolalia in autistic children: A developmental perspective. Journal of Autism and Developmental Disorders, 18(4), 657668.

McGregor, K. K., Berns, A. J., Owen, A. J., Michels, S. A., Duff, D., Bahnsen, A. J., et al. (2012). Associations between syntax and the lexicon among children with or without ASD and language impairment. Journal of Autism and Developmental Disorders, 42(1), 35-47.

Meltzoff, A. N. (1988). Infant imitation after a week delay: Long term memory for novel acts and multiple stimuli. Developmental Psychology, 24(4), 470-476.

Meltzoff, A. N., \& Moore, M. K. (1977). Imitation of facial and manual gestures by human neonates. Science, $198,75-78$.

Meltzoff, A. N., \& Moore, M. K. (1983). Newborn infants imitate adult facial gestures. Child Development, 54(3), 702-709.

Moor, J. (2002). Playing, laughing and learning with children on the autism spectrum. London: Jessica Kingsley Publishers.

Mundy, P., \& Jarrold, W. (2010). Infant joint attention, neural networks and social cognition. Neural Networks, 23(8), 985-997.

Mundy, P., \& Markus, J. (1997). On the nature of communication and language impairment in autism. Mental Retardation and Developmental Disabilities Research Reviews, 3(4), 343-349.

Mundy, P., \& Sigman, R. (1989). The theoretical implications of joint attention deficits in autism. Development and Psychopathology, 1(3), 173-183.

Mundy, P., Sigman, M., \& Kasari, C. (1990). A longitudinal study of joint attention and language development in autistic children. Journal of Autism and Developmental Disorders, 20(1), 115-128.

Nadel, J. (2006). Does imitation matter to children with autism? In S. J. Rogers \& J. H. G. Williams (Eds.), Imitation and the social mind: autism and typical development (pp. 118-137). New York, NY: The Guilford Press.

Nadel, J. (2014). How imitation boosts development: In infancy and autism spectrum disorder. Oxford: Oxford University Press.

Nadel, J., \& Aouka, N. (2006). Imitation: Some cues for intervention approaches in autism spectrum disorders. In Charman, T., \& Stone W. (Eds.), Social \& communication development in autism spectrum disorders (pp. 219-236). New York, NY: Guilford Press.

Nadel, J., Guerini, C., Peze, A., \& Rivet, C. (1999). The evolving nature of imitation as a format for communication. In J. Nadel, \& G. Butterworth (Eds.), Imitation in infancy (pp. 209-234). New York, NY: Cambridge University Press. 
Owens, R. E. (1999). Language disorders: A functional approach to assessment and intervention. Needham Heights, MA: Allyn \& Bacon.

Owens, R. E. (2012). Language development: An introduction (8th ed.). New Jersey: Pearson.

Owens, R. E., Evan-Metz, D. E., \& Haas, A. (2003). Introduction to communication disorders: A life span perspective (2nd ed.). Upper Saddle River, NJ: Pearson. Education Inc.

Ökcün-Akçamuş, M. (2015). Otizm spektrum bozukluğu olan çocuklarda söz-öncesi sosyal iletişim becerilerinin dilin bileşenleri ile ilişkisinin incelenmesi (Yayımlanmamış doktora tezi). Ankara Üniversitesi, Eğitim Bilimleri Enstitüsü, Ankara.

Paul, R. (2008). Communication development and assessment. In K. Chawarska, A. Klin \& F. R. Volkmar (Eds.), Autism spectrum disorders in infants and toddlers (pp.76-103). New York: The Guilford Press.

Pierce, S., \& Bartolucci, G. (1977). A syntactic investigation of verbal autistic, mentally retarded, and normal children. Journal of Autism and Childhood Schizophrenia, 7(2), 121-134.

Prizant, B. M., \& Duchan, J. F. (1981). The functions of immediate echolalia in autistic children. Journal of Speech and Hearing Disorders, 46(3), 241-249.

Quill, K. A. (2002). The complexity of autism. In K. A. Quill (Ed.), Do, watch, listen, say: Social and communication intervention for children with autism (pp. 1-20). Baltimore, Maryland: Paul Brookes Publishing.

Rapin, I., \& Dunn, M. (2003). Update on the language disorders of individuals on the autistic spectrum. Brain \& Development, 25(3), 166-172.

Richler, J., Bishop, S. L., Kleinke, J. R., \& Lord, C. (2007). Restricted and repetitive behaviors in young children with autism spectrum disorders. Journal of Autism and Developmental Disorders, 37(1), 73-85.

Roberts, J. M. (1989). Echolalia and comprehension in autistic children. Journal of Autism and Developmental Disorders, 19(2), 271-281.

Roberts, J. A., Rice, M. L., \& Tager-Flusberg, H. (2004). Tense marking in children with autism. Applied Psycholinguistic, 25(3), 429-448.

Rogers, S. J., Hepburn, S. L., Stackhouse, T., \& Wehner, E. (2003). Imitation performance in toddlers with autism and those with other developmental disorders. The Journal of Child Psychology and Psychiatry, 44(5), 763-781.

Rogers, S. J., \& Pennington B. F. (1991). A theoretical approach to the deficits in infantile autism. Development and Psychopathology, 3(2), 137-162.

Rowland, C. M., \& Schweigert, P. D. (2009). Object lessons: How children with autism spectrum disorders use objects to interact with the physical and social environments. Research in Autism Spectrum Disorders, 3(2), 517-527.

Schopler, E., \& Mesibov, G. B. (1985). Introduction to communication problems in autism. In E. Shopler., \& G. B. Mesibov (Eds.), Communication problems in autism (pp. 3-13). New York: Springer Science+ Business Media.

Shumway, S., \& Wetherby, A. M. (2009). Communicative acts of children with autism spectrum disorders in the second year of life. Journal of Speech, Language and Hearing Research, 52(5), 1139-1156. 
Sigman, M., \& Ruskin, E. (1999). Continuity and change in the social competence of children with autism, Down syndrome, and developmental delays. Monographs of the Society for Research in Child Development, 64(1, Serial No. 256).

Sigman, M., \& Ungerer, J. A. (1984). Cognitive and language skills in autistic, mentally retarded, and normal children. Developmental Psychology, 20(2), 293-302.

Smith, P. K. (2010). Children and play: Understanding children's worlds. West Sussex, UK: Wiley-Blackwell.

Smith, V., Mirenda, P., \& Zaidman-Zait, A. (2007). Predictors of expressive vocabulary growth in children autism. Journal of Speech, Language and Hearing Research, 50(1), 149-160.

Sowden, H., Perkins, M., \& Clegg, J. (2011). The changing role of gesture form and function in a picture book interaction between a child with autism and his support teacher. In G. Stam, \& Ishino, M (Eds.), Integrating gestures: The interdisciplinary nature of gesture (pp. 201-214). Philadelphia: John Benjamins.

Stone, W. L., Coonrod, E. E., \& Ousley, O. Y. (2000). Brief report: Screening tool for autism in two-year-olds (STAT): Development and preliminary data. Journal of Autism and Developmental Disorders, 30(6), 607-612.

Stone, W., Lemanek, K. L., Fishel, P. T., Fernandez M., C., \& Altemeier, W. A. (1990). Play and imitation skills in the diagnosis of autism in young children. Pediatrics, 86(2), 267-272.

Stone, W. L., Ousley, O. Y., \& Littleford, C. D. (1997). Motor imitation in young children with autism: What's the object? Journal of Abnormal Child and Psychology, 25(6), 475-485.

Stone, W. L., Ousley, O. Y., Yoder, P. J., Hogan, K. L., \& Hepburn, S. L. (1997). Nonverbal communication in two and three year old children with autism. Journal of Autism and Developmental Disorders, 27(6), 677-696.

Suh, J., Eigsti, I. M., Naigles, L., Barton, M., Kelley, E., \& Fein, D. (2014). Narrative Performance of optimal outcome children and adolescents with a history of an autism spectrum disorder (ASD). Journal of Autism and Developmental Disorders, 44(7), 1681-1694.

Tager-Flusberg, H. (1991). Semantic processing in the free recall of autistic children: Further evidence for a cognitive deficit. British Journal of Developmental Psychology, 9(3), 417-430.

Tager-Flusberg, H. (1992). Autistic Children's talk about psychological states: Deficits in the early acquisition of a theory of mind. Child Development, 63(1), 161-172.

Tager-Flusberg, H. (1997). Language acquisition and theory of mind: Contributions from the study of autism. In L.B. Adamson \& M.A. Romski (Eds.), Research on communication and language disorders: Contributions to theories of language development (pp. 135-160). Baltimore, MD: Paul Brookes Publishing.

Tager-Flasberg, H. (1999). A Psychological approach to understand the social and language impairments in autism. International Review of Psychiatry, 11(4), 325-334.

Tager-Flusberg, H. \& Anderson, M (1991). The development of contingent discourse ability in autistic children. Journal of Child Psychology and Psychiatry, 32(7), 1123-1134.

Tager-Flusberg, H., \& Calkins, S. (1990). Does imitation facilitate the acquisition of grammar? Evidence from a study of autistic, Down's syndrome and normal children. Journal of Child Language, 17(3), 591-606. 
Tager-Flusberg, H., Calkins, S., Nolin, T., Baumberger, T., Anderson, M., \& Chadwick-Dias, A. (1990). A longitudinal study of language acquisition in autistic and Down syndrome children. Journal of Autism and Developmental Disorders, 20(1), 1-21.

Tager-Flusberg, H., Paul, R., \& Lord, C. (2005). Communication in autism. In F. Volkmar, A. Klin, R. Paul, \& D. Cohen (Eds.), Handbook of autism and pervasive developmental disorders (3th ed. pp. 335-364). Hoboken, New Jersey: John Wiley \& Sons, Inc.

Tager-Flusberg, H., Rogers, S., Cooper, J. Landa, R., Lord, C., Paul, R., et al. (2009). Defining spoken language benchmarks and selecting measures of expressive language development for young children with autism spectrum disorders. Journal of Speech, Language, and Hearing Research, 52(3), 643-652.

Thurm, A., Bishop, S., \& Shumway, S. (2011). Developmental issues and milestones. In J. L. Matson \& P. Sturmey (Eds.), International handbook of autism and pervasive developmental disorders (pp. 159173). New York, NY: Springer.

Tomasello, M. (1995). Joint attention as social cognition. In C. Moore \& P. Dunham (Eds.), Joint attention: its origins and role in development (pp. 103-130). New York, NY: Psychology Press.

Tomasello, M. (2003). Constructing a language: A usage-based theory of language acquisition. Cambridge, MA: Harvard Universty Press.

Tomasello, M., \& Carpenter, M. (2007). Shared intentionality. Developmental Science, 10(1), 121-125.

Töret, G., \& Acarlar, F. (2011). Otizmli, Down sendromlu ve normal gelişim gösteren Türk çocukların dil öncesi dönemdeki jest kullanım becerilerinin incelenmesi. Kuram ve Uygulamada Eğitim Bilimleri, 11(3), 1461-1478.

Toth, K., Munson, J., Meltzoff, A. N., \& Dawson, G. (2006). Early predictors of communication development in young children autism spectrum disorder: Joint attention, imitation and toy play. Journal of Autism and Developmental Disorders, 36(8), 933-1005.

Turan, F., \& Ökcün-Akçamuş, M. Ç. (2013). Otistik spektrum bozukluğu olan çocuklarda taklit becerileri ve taklidin alıc1-ifade edici dil gelişimi ile ilişkilerinin incelenmesi. Türk Psikiyatri Dergisi, 24(2), 111116.

Uzgiris, I. C. (1981). Two functions of imitation during infancy. International Journal of Behavioral Development, 4(1), 1-12.

Weismer, S. E., Gernsbacher, M. A., Stronach, S., Karasinski, C., Eernisse, E. R., Venker, C. E., et al. (2011). Lexical and grammatical skills in toddlers on the autism spectrum compared to late talking toddlers. Journal of Autism and Developmental Disorders, 41(8), 1065-1075.

Westby, C. E. (2014). Social-emotional bases of pragmatic and communication development. In N. C. Singleton \& B. B. Shulman (Eds.), Language development: Foundations, processes, and clinical applications (2nd ed., pp. 119-146). Burlington, MA: Jones \& Bartlett Learning.

Wetherby, A. M. (2006). Understanding and measuring social communication in children with autism spectrum disorders. T. Charman \& W. Stone (Eds.), Social and communication development in autism spectrum disorders (pp. 3-34). New York: The Guilford Press.

Wetherby, A. M., Watt, N., Morgan, L., \& Shumway, S. (2007). Social communication profiles of children with autism spectrum disorders late in the second year of life. Journal of Autism and Developmental Disorders, 37(5), 960-975. 
Williams, E., Reddy, V., \& Costall, A. (2001). Taking a closer look at functional play in children with autism. Journal of Autism and Developmental Disorders, 31(1), 67-77.

Wilkinson, K. M. (1998). Profiles of language and communication skills in autism. Mental Retardation and Developmental Disabilities Research Reviews, 4(2), 73-79.

Wolfberg, P. J. (1994). Case illustrations of emerging social relations and symbolic activity in children with autism through supported peer play (Doctoral dissertation). Available from ProQuest Dissertations and Theses Database. (UMI No. 9505068)

Yoder, P., \& Warren, S. F. (1993). Can developmentally delayed children's language development be enhanced through prelinguistic intervention? In A. P. Kaiser \& D. B. Gray (Eds.), Enhancing children's communication: Research foundations for intervention (pp. 35-61). Baltimore: Paul H. Brookes.

Zaghlawan, H. (2011). A parent-implemented intervention to improve spontaneous imitation by young children with autism (Doctoral dissertation). University of Illisions at Urbana Champaign, ABD. Retrieved from http://hdl.handle.net/2142/26087

Zentall, T. R. (2006). Imitation: Definitions, evidence, and mechanisms. Animal Cognition, 9(4), 335-353.

Ziatas, K., Durkin, K., \& Pratt, C. (1998). Belief term development in children with autism, asperger syndrome, specific language impairment, and normal development: Links to theory of mind development. Journal of Child Psychology and Psychiatry, 39(5), 755-763.

Ziatas, K., Durkin, K., \& Pratt, C. (2003). Differences in assertive speech acts produced by children with autism, asperger syndrome, specific language impairment, and normal development. Development and Psychopathology, 15(1), 73-94.

Zwaigenbaum, L., Bryson, S., Rogers, T., Roberts, W., Brian, J., \& Szatmari, P. (2005). Behavioral manifestations of autism in the first year of life. International Journal of Developmental Neuroscience, 23(2), 143-152. 


\title{
Summary
}

\section{Social Communication Skills and Language Development of Children with Autism Spectrum Disorders*}

\author{
Meral Çilem Ökcün-Akçamuş** \\ Ankara University
}

\begin{abstract}
Autism spectrum disorder (ASD) is a developmental disorder which emerges at early stages of development and is characterized by persistent impairments in social interaction, social communication, and restricted and repetitive behaviors. Impairments in nonverbal social communication skills are one of the diagnostic criteria of autism spectrum disorders (American Psychiatric Association, 2013). According to DSM-V the severity of ASD is determined by the severity of the impairments in social communication behaviors and of the restricted behaviors. Difficulties in social communication behaviors for children with ASD are important in two ways. First, communication problems are the fundamental symptom of the autism spectrum disorder. Second, communication problems intertwine with social and cognitive problems of children with autism spectrum disorder (Schopler \& Mesibov, 1985).

In the acquisition of social communication skills children with ASD have strong and weak sides which change with the course of the development (Mundy \& Sigman, 1989). However, communication disorder is one of the fundamental impairments in children with ASD. Language and communication disorders in children with ASD can be seen in a wide range of spectrum which may include delays in speech or no speech at all, or for children who can use words or form sentences problems in effective use of language for social interactional purposes i.e., functional use of language. It is accepted that language development of children with ASD is heterogeneous. Therefore, there may be sub groups according to the characteristics of language development of
\end{abstract}

*This study is based on Meral Çilem ÖKCÜN-AKÇAMUŞ's dissertation written under the supervision of Prof. Dr. Funda ACARLAR at the Institute of Educational Sciences, Ankara University

${ }^{* *}$ Corresponding Author: Instructor, PhD, Ankara University, Faculty of Educational Sciences, Email:meralcilem@gmail.com 
children with ASD (Wilkinson, 1998). The reasons why some children with ASD acquire spoken language while some children cannot and the reasons for the degree of impairments and delays in language components are discussed in the literature (Tager-Flusberg, Paul, \& Lord, 2005).

Impairments in nonverbal social communication skills of children with ASD start to emerge very early likewise during the first year of life (Landa, 2007). Studies show that children with ASD have impairments in nonverbal social communication skills such as gestures (Camaioni, Perucchini, Muratori, Parrini, \& Cesari, 2003; Stone, Ousley, Yoder, \& Hogan, 1997; Töret \& Acarlar, 2011; Wetherby, 2006), imitation (Rogers, Hepburn, Stackhouse, \& Wehner, 2003; Stone, Ousley, \& Littleford, 1997; Turan \& Ökcün-Akçamuş, 2013), symbolic play skills (Brown \& Whiten, 2000; Charman \& Baron-Cohen, 1997) and initiating joint attention (Dawson et al., 2004; Sigman \& Ruskin, 1999). There is a limitation in gesture use for children with ASD and even though when they acquire gestures, requesting gestures emerge however limitations in commenting gestures and symbolic gestures still continue (Camaioni et al., 2003; Stone, Ousley, Yoder et al., 1997; Wetherby, 2006). Children with ASD show lower performance than both children with typical development and children with developmental delays in imitation which is a nonverbal social communication skill (Rogers et al., 2003; Stone, Ousley, \& Littleford, 1997; Turan \& Ökcün-Akçamuş, 2013), they show lower performance especially in spontaneous imitation skills than structured imitation skills (Ingersoll, 2008b). Studies show that children with ASD have limitations in play skills (Charman et al., 1997; Sigman \& Ungerer, 1984), especially in symbolic play skills children with ASD have difficulties (Brown and Whiten, 2000; Charman \& Baron-Cohen, 1997). Limitations in initiating joint attention which is one of the nonverbal social communication skills are taken as distinctive characteristic of autism (Lord et al., 2000; Wetherby, Watt, Morgan, \& Shumway, 2007).

Language development of children with ASD is heterogeneous and therefore there are individual differences in language development. While some of the children with ASD can never acquire language, the ones who have developed language skills may still have impairments in language components. Because of the fact that we have limited knowledge about the language development of nonverbal children with ASD, it is a critical issue to identify the problems in speech acquisition (Tager-Flusberg, Paul, \& Lord, 2005). Even though children with ASD start to develop spoken language, impairments related to language still continue. In language development, children with ASD have impairments especially in pragmatics (Hedge \& Maul, 2006; Lord \& Paul, 1997; Wilkinson, 1998) and impairments in the component of pragmatics take place in the diagnostic criteria of ASD (DSM-V, 2013). On the other hand, for the components of syntax, morphology some children with ASD have delays (Tager-Flusberg et al., 1990) or they omit morphemes (Bartolucci, Pierce, \& Streiner, 1980; Roberts, Rice, \& Tager-Flusberg, 2004). Studies on semantics have examined the vocabulary and use of different word types in children with ASD and showed that children have delays in word acquisition (Charman, Drew, Baird, \& Baird, 2003), they have limitations in using some words related to mental states (TagerFlusberg, 1992). Nevertheless, there are research findings which show that vocabulary of children with ASD in terms of their cognitive development is similar to their peers with typical development (Eigsti, Bennetto, \& Dadlani, 2007).

Nonverbal social communication skills are related to general language development as well as they are important in the acquisition of first words, grammatical structures (Tomasello, 2003), and the acquisition of elements of pragmatics. Nonverbal social communication skills start to emerge before the acquisition of spoken language in children and they are accounted for the precursor of language (Bruner, 1975; Tomasello, 2003). The fact that nonverbal social communication skills are precursors and predictors of language development are supported by the previous research findings (Bono, Daley, \& Sigman, 2004; Ökcün-Akçamuş, 2015; Toth, Munson, Meltzoff, \& Dawson, 2006).

\section{Önerilen Atıf Sekli}

Ökcün-Akçamuş, M. Ç. (2016). Otizm Spektrum Bozukluğu olan çocukların sosyal iletişim becerileri ve dil gelişim özellikleri. Ankara Üniversitesi Ĕ̌itim Bilimleri Fakültesi Özel Eğitim Dergisi, 17(2), 163-192. 